\title{
Ortaöğretim Öğretmenlerinin TPAB Düzeylerinin Öğretim Teknolojilerini Kullanma Durumlarına Göre İncelenmesi
}

\section{Investigation of Teachers' TPACK Levels with Respect to Use of Instructional Technologies}

\author{
Sinan Bilici, Abdurrahman Gazi IMKB Anadolu Lisesi, s.bilici84@gmail.com \\ Çetin Güler, Yüzüncü Yll Üniversitesi, cetin@yyu.edu.tr
}

\begin{abstract}
ÖZ. $\mathrm{Bu}$ araştırma, ortaöğretim öğretmenlerinin Teknolojik Pedagojik Alan Bilgisi (TPAB) düzeylerini, öğretmenlerin genel demografik özelliklerinin yanı sıra etkileşimli tahta ve diğer öğretim teknolojilerini kullanma durumlarına göre incelemeyi amaçlamaktadır. Çalıșmada karma araștırma yöntemi kullanılmıștır. Araştırmanın nicel örneklemini 2014-2015 eğitim-öğretim yılında Van ili üç merkez ilçesinde 22 ortaöğretim okulunda görev yapan değişik ders alanlarından 436 öğretmen, nitel örneklemini ise iki farklı okuldan toplam 12 öğretmen oluşturmaktadır. Veri toplama aracı olarak kişisel bilgi formu, TPAB ölçeği ve görüşme formu kullanılmıştır. Katılımcıların demografik değişkenlerine ilişkin bilgiler, frekans ve yüzde içeren betimsel istatistikler ile verilmiştir. Araştırmada veri analizi için bağımsız örneklem T-Testi, tek yönlü ANOVA testi, Tukey testi, Games-Howell testi ve Pearson korelasyon testi kullanılmıştır. Nitel veriler ise içerik analizi ile temalar altında kodlanarak sunulmuştur. Yapılan nicel analizler sonucunda öğretmenlerin cinsiyet, mesleki deneyim, eğitim düzeyi, alan, okul türü ve kategorisi, bilgisayar kullanma yeterliliği algıları, okullarında etkileșimli tahta bulunma durumları, etkileşimli tahta kullanım kursuna katılma durumları, etkileşimli tahta ve diğer öğretim teknolojilerini kullanım yeterliliği algıları ve kullanma sıklıkları değişkenlerinde anlamlı farklar görülmüştür. Araştırmada nitel verilerin analiz sonuçlarına göre ise öğretmenlerin derslerinde teknolojiyi dersin hangi bölümlerinde ve en çok hangi amaçlarla kullandıkları, derslerinde çağdaş öğretim teknolojilerini içeren ve içermeyen hangi yöntem ve tekniklere başvurdukları, günümüz öğretmenlerinin hangi yeterliliklere sahip olması gerektiği, gördükleri üniversite eğitimi ve aldıkları hizmet içi eğitimlerin bu yeterlilikleri kazandırma durumları, öğrencilerin bireysel farklılıklarına göre derslerini nasıl şekillendirdikleri ve teknoloji entegrasyonu konusunda hangi engellerle karşılaştıklarına ilişkin görüşler elde edilmiştir.

Anahtar Kelimeler: Teknolojik Pedagojik Alan Bilgisi, Etkileșimli Tahtalar, Öğretim Teknolojileri, Ortaöğretim Öğretmenleri
\end{abstract}

ABSTRACT. The aim of this study is to analyze the Technological Pedagogical Content Knowledge (TPACK) levels of high school teachers with respect to their use of interactive whiteboards and other instructional technologies. A mixed-method approach was used in the study. The quantitative sample of the research consists of 436 high school teachers and the qualitative sample consists of 12 high school teachers. Personal information form, TPACK scale and interview form were the data collection instruments. Significant differences were found in teachers' gender, professional experiences, education levels, branches, school types and categories, perceptions of the adequacy of computer using, having interactive whiteboards in the school, taking interactive whiteboard course, perceptions of the adequacy of using interactive whiteboards and other instructional technologies. Characteristics and dynamics of interactive whiteboard and other instructional design use by teachers were investigated through analysis of qualitative data.

Keywords: Technological Pedagogical Content Knowledge, Interactive Whiteboards, Instructional Technologies, High School Teachers

\section{SUMMARY}

Purpose and Significance: From the literature review, the use of interactive whiteboards and the relationship between this usage and the levels of teachers' TPACK are not seen sufficient. It has been noticed that the studies done on this subject mostly are done on pre-service teachers, and there are less studies on teachers who are in-service. Also, it is seen that there are studies mostly in the fields of mathematics and science. It is seen that in the studies the context knowledge of the theoretical framework of TPACK is less used. The aim of this study is to analyze the Technological Pedagogical 
Content Knowledge (TPACK) levels of high school teachers with respect to their general demographic characteristics as well as their use of interactive whiteboards and other instructional technologies.

Methodology: In this study parallel mixed method was used. In the parallel mixed method studies both qualitative and quantitative data are collected simultaneously. In the quantitative aspect of the study relational scanning model was used and in the qualitative aspect the method of case study was used. The theoretical population of the study is high school teachers of Turkey. The study population is 3230 in-service high school teachers who work in Van, Turkey of the year 2014 and 2015. Cluster sampling was conducted to the population and 436 teachers from 22 high schools were reached. Twelve teachers were chosen by purposive sampling from two different schools. Quantitative data was gathered by applying TPACK scale and the qualitative data was obtained by the interview form.

Results: High school teachers' average scores gathered from the scale is very good level in the CK (Content Knowledge) and PCKCx (Pedagogical Content Knowledge in Context); at a good level in TPCKCx (Technological Pedagogical Content Knowledge in Context) and general TPACK scale. In TK (Technology Knowledge), average scores remained at a lower level compared to other dimensions. Significant differences were observed in general TPACK scale and its all sub dimensions in gender, teaching experience, education level, teaching subject, school type and category, proficiency of computer use, availability of interactive whiteboards at school, attending in-service training about interactive whiteboards, proficiency of interactive whiteboards and other instructional technologies use, frequency of using interactive whiteboards and other instructional technologies.

Conclusion and Discussion: As TPACK proficiency is associated with the using of technology, for dimension of TK possible causes of having a lower level compared to other dimensions can be investigated and some arrangements can be made in this direction, education can be given and some arrangement can be made for in-service training courses. Solutions can be found to problems that teachers encountered in the integration of technology in schools. As there are significant result in the favor males for the dimensions associated with technology knowledge, positive discrimination could contribute to making women more at this point during in-service training courses. As the frequency of using the interactive whiteboards and other instructional technologies with TPACK level are in positive correlation, the possibilities of teachers to access to technologies may be increased.

\section{GíRIş}

Eğitim ve öğretimin teknolojik gelişmelerle desteklenmesi, güçlendirilmesi ve eğitimde niteliğin yükseltilmesi bakımından kara tahta, beyaz tahta, projeksiyon cihazı, bilgisayar ve etkileşimli tahta gibi öğretim araçlarının öğrenme ortamlarında etkin ve verimli şekilde kullanılması büyük önem taşımaktadır (Akyüz, Kurnaz, Pektaş ve Memiş, 2014). Özellikle yenilikçi teknolojinin bir ürünü olup geleneksel sınıflardaki beyaz ve siyah tahtanın bilgisayar teknolojisi ile birleştirildiği etkileşimli tahtalar, öğretimin kalitesini arttırmakta ve dersi daha verimli hale getirmek için yardımcı bir teknoloji olarak kullanılmaktadır (Jang ve Tsai, 2012).

Kohler, Mishra ve Yahya da (2007) tam öğrenmenin gerçekleştirilmesinde etkili teknoloji entegrasyonu için alan, teknoloji ve pedagojinin tek başına yeterli olmadığı, buna ek olarak birbiri ile olan ilişkilerinin de bilinmesi gerektiğini ifade etmişlerdir. Perkmen ve Tezci'ye göre (2011) gerekli alan bilgisi, teknolojik bilgi ve pedagojik bilginin yeterli olmasının yanında özellikle bu bilgilerin bütünleştirilmesi önemli olduğu için sınıfları teknolojiler ile donatmak, teknolojiye erişimi kolaylaştırmak ve öğretmen tutumlarını pozitif hale getirmek teknolojinin öğretime entegrasyonunu garanti etmemektedir. Örneğin bir matematik öğretmeni bir matematik konusunu hangi teknolojiyi kullanarak daha iyi öğretebileceğini biliyorsa, teknoloji entegrasyonunda başarılı sayılabilir (Niess, 2005; Schmidt vd., 2009).

Öğretmenlerin görevlerini başarı ile yürütebilecek kapasitede yetiştirilmeleri ve gerekli kriterleri sağlaması iyi bir hizmet öncesi eğitimden geçmesi ve hizmet süresi içinde de sürekli olarak 
gelişmesi ve yetişmesi ile mümkündür (Akyüz vd., 2014). Öğretmenlerin istenilen nitelikte olabilmeleri de bir takım standartların olmasına bağlıdır. Bu standardı sağlayacak yollardan birisi öğretmen yeterlilikleridir (Seferoğlu, 2004). Bu anlamda son zamanlarda nitelikli öğretmen özellikleri sorgulanmıştır. MEB (2006) tarafından, teknolojiyi derslerde etkili kullanabilme yeterliliği, öğretmen yeterlilikleri arasında gösterilmiştir. ISTE (2008) (Uluslararası Eğitimde Teknoloji Topluluğu) ise öğretmenlerin derslerinde teknoloji kullanabilmeleri için bilgisayar teknolojisindeki temel ișlemler ve kavram bilgisi, kendi mesleki gelișimleri için teknolojiyi kullanma bilgisi ve öğretim ortamlarında teknoloji kullanım bilgisi şeklinde üç alanda öğretmenlerin yeterli olmaları gerektiğini belirtmiştir.

Ülke genelinde tüm derslikleri etkileşimli tahtalarla buluşturmayı hedefleyen FATíH projesinin (MEB, 2012) öğretmenler tarafından yeterince benimsenip benimsenmediği, sunulan teknolojik imkanların etkin şekilde kullanılıp kullanılmadığı, okulların TPAB çerçevesinde entegrasyon düzeyleri ve bu teknolojileri kullanan öğretmenlerin TPAB yeterliliklerinin ortaya çıkarılması, hem öğretmen hem de öğrenci başarısının arttırılması açısından önemlidir (Karakaya, 2013; Koehler ve Mishra, 2005).

\section{Öğretim Teknolojileri ve Etkileşimli Tahtalar}

Eğitim ortamlarında çoklu ortam içerikli araç-gereç kullanımları etkili bir öğrenme ortamı oluşturarak öğrencilerin belirlenen hedeflere daha kolay şekilde ulaşmalarında ve başarıyı yakalamalarında önemli yer tutar (Çelik, 2007). Etkileşimli tahta gibi öğretim teknolojisi kapsamındaki görsel, işitsel, teknolojik malzeme ve kaynakların en önemli özellikleri öğrenmeöğretme ortamlarının zenginleştirmesi, soyut durumların somutlaştırması, öğrencinin öğretim sürecine aktif bir şekilde katılım sağlaması ve daha az zaman harcanmasıdır (Fer, 2004). Ayrıca etkileşimli tahtaların öğrenme ortamlarında kullanılması farklı ve ilginç etkinlikler ile zengin içerikler içeren e-öğrenme içerikleri, oyun tabanlı öğrenmeler, web tabanlı öğrenme ortamları ve eğitsel yazılımların kullanılmasına olanak sağlamaktadır (Çelen, Çelik ve Seferoğlu, 2011).

Alanyazında öğrenme ortamlarına entegre edilen etkileşimli tahtaların kullanımı ile ilgili olarak farklı derslerde, öğretmenler, öğrenciler ve idarecileri kapsayan birçok çalışmaya rastlanmaktadır. Yapılan çalışmalarda çoğunlukla etkileşimli tahtaların öğrencilerin motivasyonu (Akçayır, 2011; Katwibun, 2014), akademik başarısı (Akçayır, 2011; Akdemir, 2009; Amiri ve Sharifi, 2014; Katwibun, 2014; Öztan, 2012; Zengin, Kırılmazkaya ve Keçeci, 2011; Uzun, 2013) ve tutumları (Akçayır, 2011; Katwibun, 2014; Koçak, 2013; Zengin vd., 2011) üzerindeki etkisine bakılmıștır. Bazı çalışmalar ise birden fazla değişken açısından incelemişlerdir (Ateş, 2010; Tatlı ve E.Kılıç, 2015). Öğretmen ve idarecilerin etkileşimli tahta kullanılan öğretim süreçleri ile ilgili olumlu ve olumsuz görüşlerine de başvurulan çalışmalar vardır (Altınçelik, 2009; Bakadam ve Asiri, 2012; Bulut ve Koçoğlu, 2012; Elaziz, 2008; Smith, Higgins, Wall ve Miller, 2005; Türel, 2012; Tataroğlu ve Erduran, 2009).

\section{Teknolojik Pedagojik Alan Bilgisi ve Bileşenleri}

TPAB yaklaşımın temelinde Shulman'ın (1986) öne sürdüğü ve öğretmen eğitiminde konu alan bilgisinin pedagoji bilgisi ile bir bütün olarak ve aynı anda kullanılması gerektiğini savunan Pedagojik Alan Bilgisi (PAB) yaklaşımı yatmaktadır. TPAB, pedagojik alan bilgisine teknoloji boyutunun eklenmesi ile ortaya çıkmış ve bir araya gelen alan, pedagoji ve teknoloji bilgi türlerinin ötesinde bir bilgi türü olarak tanımlanmıștır (Mishra ve Koehler, 2006).

Mishra ve Koehler (2006) tarafından ortaya atılan TPAB modeli, etkili bir teknoloji entegrasyonu sağlamak için gerekli öğretmen bilgisinin hangi öğelerden oluşması gerektiğini ortaya koymaktadır. TPAB modeline göre öğretmenlerin eğitimleri esnasında alan bilgisi, pedagoji bilgisi ve teknoloji bilgisi olmak üzere üç temel bilgi boyutunu öğrenmeleri istenir. Bu bilgi yapılarının birbirinden ayrık olmadığı ve birbiri ile etkileşim halinde, aralarında dinamik bir ilişkinin olduğu savunulmaktadır (Koehler, Mishra ve Yahya, 2007). Bu üç temel bilgi boyutunun yanında bunların birbiri ile etkileşimi sonucu ortaya yeni alt bilgi boyutları da ortaya çıkmıştır. TPAB bilgisi, üç farklı 
bilginin ötesinde yeni bir yapı olarak düşünülür ve teknoloji ile tam öğrenmenin entegrasyonu temeline dayandırılır. Mishra ve Koehler (2006) etkili bir eğitimin konu alanı ve öğretim alanına teknolojinin salt ve basit şekilde eklenmesi ile değil, teknoloji yardımıyla yeni kavramların farklı öğretim şekilleri ile sunulması ve aynı zamanda TPAB'ın çerçevesini oluşturan bu üç öğenin birbiriyle dinamik bir yapıda ilişkili olması gerektiğini ifade etmiştir.

\section{Araştırmanın Amacı ve Önemi}

Alanyazın incelendiğinde etkileşimli tahta kullanımı ile bu kullanımın öğretmenlerin TPAB düzeyleri ile ilişkisi üzerine yapılan çalışmaların yeterli olmadığı görülmektedir (Akyüz vd., 2014; Jang ve Tsai, 2012). Bu konuyla ilgili yapılan çalışmaların çoğunlukla öğretmen adayları ile yapıldığı (Abbitt, 2011; Akgün, 2013; Akkaya, 2009; Chai, Koh, Tsai ve Tan, 2011; Gömleksiz ve Fidan, 2011; Yurdakul-Kabakçı, 2011; Koh ve Divaharan, 2011; Timur, 2011), görev yapan öğretmenlere yönelik çalışmaların ise (Archambault ve Crippen, 2009; Avcl, 2014; Jang, 2010; Karataş, 2014; Lye, 2013; Özbek, 2014) daha az olduğu fark edilmiştir. İkinci olarak,TPAB ile ilgili daha çok matematik (Akkaya, 2009; Avcl, 2014; Ergene, 2011; Karataș, 2014; Niess, 2005) ve fen bilimleri (Canbazoğlu-Bilici, 2012; Canbolat, 2011; Graham vd., 2009; A.Kılıç, 2011; Timur ve Taşar, 2011) alanlarında çalışma yapıldığı görülmektedir. $\mathrm{Bu}$ açıdan bakıldığında bu çalışma değişik ders alanlarını bir arada inceleyen bir çalışma olması nedeniyle önem taşımaktadır.

Bu çalışmayı önemli kılan bir diğer etken ise bağlam bilgisidir. Bağlam bilgisi, öğretmenin görev yaptığı bölgenin şartları, bu şartların içinde yer alan firsat ve sinırlılıkları, okul kültürünü, okulda öğretimi etkileyen bağlamsal faktörleri, öğrencilerin aile yapıları, demografik özellikleri, geçmiş yaşantıları, bilgi ve beceri durumları, güçlü ve zayıf yönleri, öğretmen ve öğrencilerin fiziksel ve psikolojik özellikleri hakkında bilgileri kapsar (Grossman, 1990). Bağlam bilgisinin TPAB kuramsal çerçevesini kullanan çalışmalarda ise daha az ele alındığı görülmektedir (Angeli ve Valanides, 2008; Canbazoğlu-Bilici, 2012; Karakaya, 2013). Bu çalışmada öğretmenlerden veri toplamak için kullanılan ölçekte, alanyazındaki TPAB ölçeklerindeki “Bağlam (context) tabanlı bilgi” eksikliği giderilmekte ve özel durumlara göre kullanılacak teknolojik, pedagojik ve alan bilgisine vurgu yapılmaktadır (Jang ve Tsai, 2012).

$\mathrm{Bu}$ çalışmayı önemli kılan bir nokta da, son yıllarda öğretim teknolojilerinin Türkiye genelindeki tüm okullarda eğitim ve öğretimde firsat eşitliğini sağlamayı ve okullardaki teknolojiyi iyileştirmeyi hedefleyen FATIH projesinin başlatılmış olmasıdır (MEB, 2012). Bu proje kapsamında okul öncesinden liseye kadar tüm sınıflarda etkileşimli tahta ve internet ağ altyapısının sağlanması amaçlanmaktadır. Dolayısıyla etkileşimli tahta kullanımının FATİH projesiyle birlikte ülke genelinde kazanmakta olduğu yaygınlık göz önünde bulundurulduğunda bilişim teknolojileri donanımlarının öğrenme-öğretme sürecinde pedagoji ve alan bilgisi ile birlikte etkin kullanımı daha da önem kazanmaktadır (Kayaduman, Sırakaya ve Seferoğlu, 2011).

\section{Problem Cümlesi}

Ortaöğretim öğretmenlerinin TPAB düzeyleri etkileşimli tahta ve diğer öğretim teknolojilerini kullanma durumlarına göre nasıl farklılaşmaktadır?

\section{Alt Problemler}

Ortaöğretim öğretmenlerinin TPAB'ları;

- Ne düzeydedir?

- Cinsiyete, yaşa, mesleki deneyime, eğitim düzeyine, alana, mezun olunan fakülte türüne, görev yapılan okul türü ve kategorisine, bilgisayar kullanma yeterliliği algısına ve bilgisayar kullanma sıklığına göre değişmekte midir?

- Okullarında etkileşimli tahta bulunma, etkileşimli tahta ve diğer öğretim teknolojileri kursu alıp almama durumuna göre farklılaşmakta mıdır?

- Etkileșimli tahta ve diğer öğretim teknolojilerini kullanma yeterliliği algısına ve kullanma sıklığına göre değişmekte midir? 
Ortaöğretim öğretmenlerinin;

- Sınıfta etkileşimli tahta ve diğer öğretim teknolojilerini kullanma durumları nasıldır?

- Etkileşimli tahta ve diğer öğretim teknolojilerini kullanmaya ilişkin olumlu-olumsuz görüşleri, yeterlilik durumlarına ilişkin algıları ve karşılaştıkları engeller nelerdir?

\section{YÖNTEM}

\section{Araștırma Deseni}

Ortaöğretim öğretmenlerinin TPAB düzeylerinin belirlenmesi amacıyla gerçekleştirilen bu çalışmada karma yöntemler araştırma yöntemi kullanılmıștır. Karma yöntemler araștırması, araştırma problemlerine yanıtlar bulmak için nicel ve nitel verilerin bir veya birden fazla çalışma dizisi ile elde edilmesi, analiz edilmesi ve birbiri ile ilişkilendirilmesini hedefleyen bir araştırma yöntemidir (Creswell, 2013). Bu çalıșmada paralel karma yöntemi kullanılmıştır. Paralel karma yöntem araştırmalarında eş zamanlı olarak hem nitel hem de nicel veriler toplanır ve daha sonra bu veriler birleştirilerek araştırma problemini anlamak için çıkarılan sonuçlar kullanılır.

Çalışmanın nicel boyutunda ilişkisel tarama modeli, nitel boyutunda ise durum çalışması modeli kullanılmıştır. İlişskisel tarama modelleri, iki ya da daha çok sayıda değişkenin aralarındaki ilişkilerin de belirlenmek üzere incelendiği tarama modelleri, durum çalışması ise bir durum hakkında detaylı betimlemeler yapmak ve o durumu var olduğu şekliyle anlamaya yöneliktir (Büyüköztürk, Kılıç-Çakmak, Akgün, Karadeniz ve Demirel, 2013).

\section{Evren Ve Örneklem}

Araştırma evrenini 2014-2015 eğitim öğretim yılında Van ilinin 13 ilçesinde görev yapan değişik ders alanlarındaki toplam 3230 öğretmen oluşturmaktadır. Araştırmada nicel örneklem için okul yoğunluğunun en fazla olduğu üç merkez ilçe (Tuşba, İpekyolu ve Edremit) belirlenmiştir. Her bir ilçedeki okullar arasından ise küme örnekleme yoluyla seçilen toplam 22 ortaöğretim okulunda görev yapan 456 öğretmene ulaşılmıştır. 20 öğretmen anketin yarısından fazlasını doldurmadığı için değerlendirmeye alınmamıştır. Nitel örneklem olarak, iki farklı okuldan toplam 12 öğretmen amaçlı örnekleme yoluyla seçilmiştir. Bu örnekleme türü çalışmanın amacına bağlı olarak bilgi açısından zengin durumların seçilerek derinlemesine araştırma yapılmasına olanak tanır (Büyüköztürk vd., 2013).

\section{Veri Toplama Araçları}

Çalışmada hem nicel hem de nitel veri toplama araçları kullanılmıştır. Örneklem guruba uygulanan TPAB ölçeği ile nicel veriler, görüșme formu ile nitel veriler elde edilmiştir.

\section{TPAB Ölçeği}

Çalışmada uyarlaması yapılarak kullanılan TPAB ölçeği Jang ve Tsai (2012) tarafından geliştirilmiştir. Bu TPAB ölçeğinde bağlam bilgisi ile ilişkili olarak öğrencilerin önceki öğrenmeleri, öğrenme güçlükleri, öğrenci ile nasıl etkileşime geçildiği ve öğrenci değerlendirilmesi gibi bilgiler içeren maddeler de yer almaktadır. Orijinal ölçek 5’li Likert tipinde, 1-Kesinlikle Katılmıyorum, 2Katılmıyorum, 3-Az Katılıyorum, 4-Katılıyorum ve 5-Tamamen Katılıyorum şeklinde sıralanmıştır.

Ölçek uyarlama işlemlerinde özgün ölçek ile uyarlanmış ölçek arasındaki farklılıkların en aza indirilmesi için ölçeğin dayandırıldığı kuramsal temellere bağlı kalınması önemlidir (Kaya, Kaya ve Emre, 2013). Uyarlama sürecine başlanmadan önce makalenin birinci yazarı olan Syh-Jong Jang'dan elektronik posta yoluyla izin alınmıştır. Daha sonra, TPAB ölçeği her iki dili de iyi bilen ve ilgili konuya hâkim üç uzman tarafından İngilizce'den Türkçe'ye birbirinden bağımsız şekilde çevrilmiştir. Ardından, çevirisi yapılan orijinal ölçek ile karşılaştırılması ve ölçekteki ifadelerin eşdeğerliğinin sınanması amacıyla iki uzman tarafından da geri-çeviri yapılarak kontrol edilmiştir. Uzman çevirilerinde gözlenen az sayıda farklılık bir alan uzmanı desteğiyle giderilmiştir. Çevirisi yapılan ölçek son olarak Türkçe dilbilgisi açısından incelenmek üzere bir Türk Dili ve Edebiyatı öğretmenin görüşüne sunulmuştur. Son hali verilen ölçeğin bir ortaöğretim okulunda 21 öğretmen ile pilot 
uygulaması yapılmış ve ölçeğin hem okunabilirliği hem de anlaşılabilirliği test edilerek gerekli iyileștirmeler yapılmıştır.

Tablo 1. Öğretmenlerin bazı demografik özellikleri

\begin{tabular}{|c|c|c|c|c|c|}
\hline & Frekans & Yüzde & $\begin{array}{l}\text { Devlet } \\
\text { Özel }\end{array}$ & $\begin{array}{l}373 \\
63\end{array}$ & $\begin{array}{l}86 \\
14\end{array}$ \\
\hline Cinsiyet & & & $\begin{array}{l}\text { Bilgisayar Kullanma } \\
\text { Yeterliliği Algıları }\end{array}$ & & \\
\hline $\begin{array}{l}\text { Erkek } \\
\text { Kadın }\end{array}$ & $\begin{array}{l}292 \\
144 \\
\end{array}$ & $\begin{array}{l}67 \\
33 \\
\end{array}$ & Düşük & 28 & 6 \\
\hline Yaş & & & $\begin{array}{l}\text { Orta } \\
\text { İleri }\end{array}$ & $\begin{array}{l}279 \\
103\end{array}$ & $\begin{array}{l}64 \\
24\end{array}$ \\
\hline $20-25$ yaş arası & 54 & 12 & Uzman & 26 & 6 \\
\hline $\begin{array}{l}26-30 \text { yaș arası } \\
31-35 \text { yaș arası } \\
36-40 \text { yaș arası } \\
41 \text { yaș ve üstü }\end{array}$ & $\begin{array}{l}152 \\
110 \\
85 \\
35\end{array}$ & $\begin{array}{l}35 \\
25 \\
20 \\
8\end{array}$ & $\begin{array}{l}\text { Etkileşimli Tahta } \\
\text { Kullanım Yeterliliği } \\
\text { Algıları }\end{array}$ & & \\
\hline Mesleki Deneyim & & & Düşük & 94 & 22 \\
\hline 1-5 Yll Arasl & 188 & $\begin{array}{l}43 \\
25\end{array}$ & $\begin{array}{l}\text { Orta } \\
\text { İleri }\end{array}$ & $\begin{array}{l}257 \\
85\end{array}$ & $\begin{array}{l}59 \\
19 \\
\end{array}$ \\
\hline $\begin{array}{l}\text { 6-10 Yıl Arası } \\
\text { 11-15 Yıl Arası }\end{array}$ & $\begin{array}{l}109 \\
87\end{array}$ & 20 & Etkileşimli Tahta & & \\
\hline 16-20 Yıl Arası & 41 & 9 & Kullanma Sıklığı & & \\
\hline 21 Yll ve Üstü & 11 & 3 & Her ders (sık sık) & 129 & 30 \\
\hline Eğitim Düzeyi & & & $\begin{array}{l}\text { Sadece belirli } \\
\text { konularda }\end{array}$ & 152 & 35 \\
\hline $\begin{array}{l}\text { Lisans } \\
\text { Lisansüstü }\end{array}$ & $\begin{array}{l}302 \\
134 \\
\end{array}$ & $\begin{array}{l}69 \\
31\end{array}$ & konularda & 51 & 12 \\
\hline Alan & & & $\begin{array}{l}\text { Ayda birkaç kez } \\
\text { Hiç }\end{array}$ & $\begin{array}{l}28 \\
76\end{array}$ & $\begin{array}{l}6 \\
17\end{array}$ \\
\hline Matematik & 57 & 13 & Etkileşimli Tahtanın & & \\
\hline Edebiyat & 87 & 20 & En Çok Kullanılma & & \\
\hline Felsefe Grubu & 16 & 4 & Amaci & & \\
\hline Yabancı Dil & 45 & 10 & & & \\
\hline Fen Bilimleri Grubu & 56 & 13 & Yazı yazma/çizim & 55 & 13 \\
\hline Sosyal Bilimler Grubu & 53 & 12 & yapma & & \\
\hline Meslek Dersleri Grubu & 69 & 16 & İnternete bağlanma & 29 & 7 \\
\hline Genel Yetenek & 29 & 7 & Sunum yapma & 207 & 48 \\
\hline Dersleri Grubu & & & Film ve video & 62 & 14 \\
\hline Diğer & 24 & 5 & gösterme & & \\
\hline Mezun Olunan & & & Diğer & 14 & 3 \\
\hline Fakülte Türü & & & $\begin{array}{l}\text { Etkileşimli Tahtanın } \\
\text { Kullanıldığı Ders }\end{array}$ & & \\
\hline Eğitim Fakültesi & 200 & 46 & Aşaması & & \\
\hline Teknik Eğitim & 31 & 7 & & & \\
\hline Fakültesi & & & Başında & 75 & 17 \\
\hline Fen Edebiyat & 161 & 37 & Ortasında & 100 & 23 \\
\hline Fakültesi & & & Sonunda & 24 & 6 \\
\hline $\begin{array}{l}\text { Eğitim Ens./Yüksek } \\
\text { Okulu }\end{array}$ & 20 & 5 & Sürekli & 166 & 38 \\
\hline Diğer & 24 & 5 & \multirow{2}{*}{\multicolumn{3}{|c|}{$\begin{array}{l}\text { Etkileşimli Tahtanın } \\
\text { Gerekli Görülme } \\
\text { Durumu }\end{array}$}} \\
\hline Okul Kategorisi & & & & & \\
\hline Anadolu Lisesi & 209 & 48 & & & \\
\hline Kız Meslek Lisesi & 34 & 8 & Her zaman & 149 & 35 \\
\hline Fen Lisesi & 35 & 8 & Çoğunlukla & 142 & 34 \\
\hline $\begin{array}{l}\text { Endüstri Meslek Lisesi } \\
\text { İmam Hatin Lisesi }\end{array}$ & $\begin{array}{l}74 \\
54\end{array}$ & $\begin{array}{l}17 \\
12\end{array}$ & Zaman zaman & 108 & 25 \\
\hline $\begin{array}{l}\text { Imam Hatip Lisesi } \\
\text { Sağlık Meslek Lisesi }\end{array}$ & $\begin{array}{l}54 \\
30\end{array}$ & $\begin{array}{l}12 \\
7\end{array}$ & Nadiren & 21 & 5 \\
\hline Okul Türü & & & Hiç & 2 & 1 \\
\hline
\end{tabular}


Örneklemden elde edilen veriler kullanılarak ölçeğin geçerlik ve güvenirlik çalışmalarına yönelik analizler yapılmıştır. Ölçeğin söz konusu örneklem grup üzerinde nasıl bir yapı gösterdiğini görmek ve yapı geçerliliğini sağlamak için açımlayıcı faktör analizi yapılmıştır. Örneklem büyüklüğünün analiz yapılabilmesi için uygun olup olmadığını görmek üzere Kaiser-Mayer-Oklin (KMO) Testi ve Barlett Küresellik Testi uygulanmıștır. Verilerin faktör analizine uygun sayılabilmesi için KMO değeri .60'dan yüksek ve Barlett testi de anlamlı çıkmalıdır (Büyüköztürk, 2007). Tablo 2 'deki test sonuçlarına göre KMO değeri .943 ve Barlett testi ise anlamlı bulunmuştur $\left(X^{2}=9523,703\right.$, $\mathrm{df}=435, \mathrm{p}<0.01$ ).

Tablo 2. Ölçeğe ait KMO ve Barlett Küresellik Testi Değerleri

\begin{tabular}{ll}
\hline Kaiser-Meyer-Olkin örneklem yeterlilĭ̆i & .943 \\
Bartlett küresellik testi Ki-kare değeri & 9523.703 \\
Sd & 435 \\
p & .000 \\
\hline
\end{tabular}

Orijinal ölçek 4 faktörlü olduğu için faktör sayısı 4 olarak ayarlanarak Varimax döndürme ile faktör analizi uygulanmıştır. Bu analiz sonucunda Tablo 3'teki gibi 4 faktörlü ve özgün ölçeğe benzer bir yapı elde edilmiştir. Ölçek maddelerinin faktör yükleri 0.40 ve üzerinde alınmıştır. Bir maddenin iki faktör için yüksek yük değeri vermesi halinde, bu yük değerleri arasındaki farkın en az 0.10 olmasına dikkat edilmiştir (Büyüköztürk, 2007).

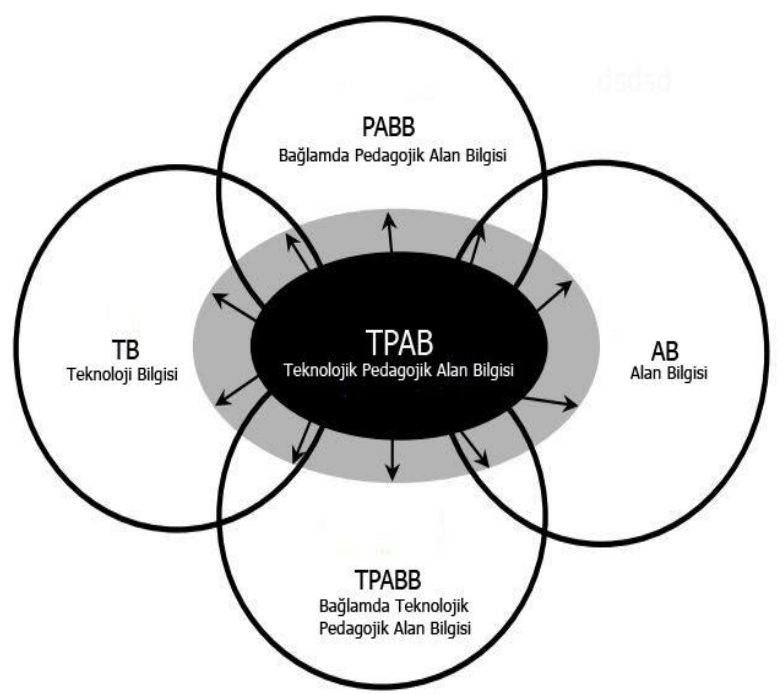

Şekil 1. Bağlamsallaştırılmış TPAB Modeli (Jang ve Tsai, 2013) 
Tablo 3. Açımlayıcı faktör analizi sonucu döndürülmüş̧ faktör yük değerleri

\begin{tabular}{|c|c|c|c|c|c|}
\hline & & & & ler & \\
\hline \multirow{13}{*}{ } & Madde & 1 & 2 & 3 & 4 \\
\hline & M26 & .843 & & & \\
\hline & M23 & .842 & & & \\
\hline & M25 & .842 & & & \\
\hline & M21 & .839 & & & \\
\hline & M24 & .838 & & & \\
\hline & M29 & .824 & & & \\
\hline & M27 & .817 & & & \\
\hline & M22 & .816 & & & \\
\hline & M20 & .796 & & & \\
\hline & M30 & .739 & & & \\
\hline & M28 & 690 & & & \\
\hline & M19 & .664 & & & \\
\hline \multirow{9}{*}{ 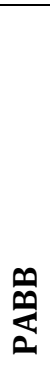 } & M12 & & .724 & & \\
\hline & M7 & & .708 & & \\
\hline & M6 & & .701 & & \\
\hline & M8 & & .661 & & \\
\hline & M13 & & .647 & & \\
\hline & M11 & & .643 & & \\
\hline & M14 & & .587 & & \\
\hline & M9 & & .550 & & \\
\hline & M10 & & .544 & & \\
\hline \multirow{5}{*}{$\stackrel{q}{\varepsilon}$} & M2 & & & .839 & \\
\hline & M3 & & & .800 & \\
\hline & M1 & & & .748 & \\
\hline & M4 & & & .626 & \\
\hline & M5 & & & .610 & \\
\hline \multirow{4}{*}{$\stackrel{n}{H}$} & M17 & & & & .766 \\
\hline & M18 & & & & .734 \\
\hline & M15 & & & & .699 \\
\hline & M16 & & & & .646 \\
\hline
\end{tabular}

Son durumda 30 madde ve 4 faktörden oluşan ölçek, Alan Bilgisi (AB) boyutu, Bağlamda Pedagojik Alan Bilgisi (PABB) boyutu, Teknoloji Bilgisi (TB) boyutu ve Bağlamda Teknolojik Pedagojik Alan Bilgisi (TPABB) boyutu şeklinde guruplanmıștır (bkz. Şekil 1).

Dört faktörden oluşan analiz sonucunda açıklanan toplam varyans Tablo 4'teki gibi \%64.62 olmuştur. Birinci faktörün öz değeri 11.88, açıkladığı varyans \%39.61; ikinci faktörün öz değeri 4.64, açıkladığı varyans \%15.48; üçüncü faktörün öz değeri 1.52 açıkladığı varyans \%5.06 ve dördüncü faktörün öz değeri 1.33, açıkladığı varyans \% 4.45 olarak bulunmuştur. Birinci faktöre ilişkin yük değerleri .664 ile .843 arasında, ikinci alt faktöre ilişkin yük değerleri .544 ile .724 arasında, üçüncü alt faktöre ilişkin yük değerleri .610 ile .839 arasında ve dördüncü alt faktöre ilişkin yük değerleri ise .646 ile .766 arasında değişmiştir. 
Tablo 4. Açımlayıcı faktör analizi sonucu açılklanan varyans değerleri

\begin{tabular}{|c|c|c|c|c|c|c|c|c|c|}
\hline & \multicolumn{3}{|c|}{ Başlangıç Özdeğerleri } & \multicolumn{3}{|c|}{$\begin{array}{c}\text { Toplam Açıklanan Varyans Yük } \\
\text { Değerleri }\end{array}$} & \multicolumn{3}{|c|}{$\begin{array}{l}\text { Döndürme(rotasyon) } \\
\text { sonrası yük değerleri }\end{array}$} \\
\hline & Toplam & $\begin{array}{l}\text { Varyans } \\
(\%)\end{array}$ & $\begin{array}{c}\text { Yığmalı } \\
(\%)\end{array}$ & Toplam & $\begin{array}{l}\text { Varyans } \\
(\%)\end{array}$ & $\begin{array}{l}\text { Yı̆̆malı } \\
(\%)\end{array}$ & Toplam & $\begin{array}{c}\text { Varyans } \\
(\%)\end{array}$ & $\begin{array}{c}\text { Yığmalı } \\
(\%)\end{array}$ \\
\hline 1 & 11.886 & 39.619 & 39.619 & 11.886 & 39.619 & 39.619 & 8.603 & 28.677 & 28.677 \\
\hline 2 & 4.646 & 15.487 & 55.105 & 4.646 & 15.487 & 55.105 & 4.541 & 15.135 & 43.812 \\
\hline 3 & 1.520 & 5.066 & 60.171 & 1.520 & 5.066 & 60.171 & 3.183 & 10.609 & 54.420 \\
\hline 4 & 1.336 & 4.455 & 64.626 & 1.336 & 4.455 & 64.626 & 3.062 & 10.205 & 64.626 \\
\hline 5 & 1.042 & 3.474 & 68.099 & & & & & & \\
\hline 6 & .876 & 2.918 & 71.018 & & & & & & \\
\hline 7 & .718 & 2.394 & 73.411 & & & & & & \\
\hline 8 & .701 & 2.336 & 75.748 & & & & & & \\
\hline 9 & .630 & 2.100 & 77.848 & & & & & & \\
\hline 10 & .614 & 2.047 & 79.895 & & & & & & \\
\hline 11 & .515 & 1.716 & 81,611 & & & & & & \\
\hline 12 & .476 & 1.585 & 83.196 & & & & & & \\
\hline 13 & .446 & 1.487 & 84.684 & & & & & & \\
\hline 14 & .441 & 1.468 & 86.152 & & & & & & \\
\hline 15 & .386 & 1.286 & 87.438 & & & & & & \\
\hline 16 & .362 & 1.206 & 88.643 & & & & & & \\
\hline 17 & .357 & 1.190 & 89.833 & & & & & & \\
\hline 18 & .349 & 1.163 & 90.997 & & & & & & \\
\hline 19 & .320 & 1.067 & 92.063 & & & & & & \\
\hline 20 & .315 & 1.052 & 93.115 & & & & & & \\
\hline 21 & .291 & .971 & 94.086 & & & & & & \\
\hline 22 & .265 & .884 & 94.970 & & & & & & \\
\hline 23 & .241 & .804 & 95.774 & & & & & & \\
\hline 24 & .238 & .792 & 96.566 & & & & & & \\
\hline 25 & .213 & .710 & 97.276 & & & & & & \\
\hline 26 & .191 & .638 & 97.914 & & & & & & \\
\hline 27 & .173 & .575 & 98.490 & & & & & & \\
\hline 28 & .168 & .561 & 99.051 & & & & & & \\
\hline 29 & .156 & .520 & 99.571 & & & & & & \\
\hline 30 & .129 & .429 & 100.000 & & & & & & \\
\hline
\end{tabular}

Ölçeğin güvenirliğini test etmek için Cronbach alfa iç tutarlılık katsayı değerleri hesaplanmış ve Tablo 5'teki gibi bulunmuştur. Alfa güvenirlik katsayıları alt boyutlarda AB (.863), PABB (.866), TB (.896) ve TPABB (.959) şeklinde hesaplanmıștır. Tüm ölçeğin güvenirlik katsayısı ise (.946) çıkmıştır. İç tutarlılık katsayı değerlerinin hepsinin .85'den yüksek çıkmış olması ölçeğin güvenirlik değerlerinin oldukça yüksek olduğuna ve tutarlı veriler ürettiğine işaret etmektedir.

Tablo 5. Faktörlere ait Cronbach alfa iç tutarlılık katsayı değerleri

\begin{tabular}{lc}
\hline Boyutlar & Cronbach Alfa Değeri \\
\hline Alan Bilgisi & .863 \\
Bağlamda Pedagojik Alan Bilgisi & .866 \\
Teknoloji Bilgisi & .896 \\
Bağlamda Teknolojik Pedagojik Alan Bilgisi & .959 \\
Tüm Ölçek & .946 \\
\hline
\end{tabular}

TPAB ölçeği ve faktörleri arasındaki ilişkiye Pearson korelasyon testi ile bakılmıştır. Tablo 6'da yer alan verilere göre, ölçeğin toplam puanı ile faktör puanları arasındaki korelasyonların .593 
ile .887 arasında, alt faktörlerin kendi aralarındaki korelasyonlarının ise .265 ile .692 arasında değiştiği görülmüștür. Korelasyon katsayısının mutlak değer olarak 0.70-0.99 arasında olması yüksek, 0.69-0.30 arasında olması orta, 0.29-0.01 arasında olması ise düşük düzeyde bir ilişki olarak tanımlanabilir (Büyüköztürk vd., 2013). Buna göre, toplam faktör ile diğer faktörler arsında çoğunlukla yüksek düzeyde, pozitif ve anlamlı bir ilişki; alt faktörlerin kendi aralarında ise çoğunlukla orta düzeyde, pozitif yönde ve anlamlı bir ilişki ortaya çıkmıştır.

Tablo 6. TPAB ölçeğindeki alt boyutlar ve toplam ölçek arasındaki korelasyon değerleri

\begin{tabular}{llllll}
\hline & AB & PABB & TB & TPABB & TOPLAM \\
\hline AB & --- & & & & \\
PABB & $.654^{* *}$ & --- & & & \\
TB & $.354^{* *}$ & $.418^{* *}$ & --- & & \\
TPABB & $.265^{* *}$ & $.366^{* *}$ & $.692^{* *}$ & --- & \\
TOPLAM & $.593^{* *}$ & $.706^{* *}$ & $.805^{* *}$ & $.887^{* *}$ & -- \\
\hline
\end{tabular}

\section{Nitel Veri Toplama Aracı}

On bir soruluk yarı yapılandırılmış görüşme formu ile veriler 20 dakika süren görüşmeler sonucunda 12 öğretmenden toplanmıştır. Görüşme formu hazırlanırken TPAB bileșenleri ile paralel olmasına ve öğretmenlerin bu yöndeki görüşlerini elde etmeyi sağlayacak şekilde hazırlanmasına dikkat edilmiştir. Geliştirilen görüşme formu iki alan uzmanına sunulmuş ve öneriler doğrultusunda gerekli değişiklikler yapıldıktan sonra uygulanmıştır. Görüşmeye geçilmeden önce öğretmenlerden ses kaydı için izinler alınmıştır.

\section{Nicel Verilerin Analizi}

Nicel verilerin analizinde demografik değişkenlerin dağılımını belirlemek için betimsel istatisik (frekans ve yüzde) ve demografik değişkenler ile ölçek faktör puanları arasındaki ilişkiyi test etmek için yordayıcı istatistikler (bağımsız örneklem t-testi ve ANOVA) kullanılmıștır. ANOVA testi uygulandığında varyansların homojen dağıldığı durumlarda Tukey, dağılmadığı durumlarda ise Games-Howell testi kullanlmıştır. Games-Howell testi, eşit olmayan varyanslar ve eşit olmayan örneklem boyutları için uygun bir testtir (Games, Keselman ve Clinch, 1979). Ayrıca ölçek faktörleri arasındaki ilişki düzeyini tespit etmek için de Pearson korelasyon testi uygulanmıștır.

\section{Nitel Verilerin Analizi}

Görüşme metinlerinin analizinde içerik analizi yöntemi kullanılmıştır. Öğretmenler ile yapılan görüşmeler önce ses kaydına alınmış daha sonra bu ses kayıtları yazılı metin haline getirilmiş ve öğretmenlerden görüşmenin yazılı hali için onay alınarak nitel analizler için güvenirlik ve geçerlilik sağlanmıştır. Öğretmen görüşleri analiz edilirken karışıklık olmaması için her bir öğretmene Ö1'den Ö12'ye kadar isimlendirme yapılmıştır. Yazılı görüşlerden elde edilen kodlar alanyazından yararlanılarak belirli temalar altında toplanmış; tema ve kodlamaların uygunluğu, ilgili alanda nitel çalışma yapmış uzman görüşüne sunulmuştur.

\section{BULGULAR}

Yapılan analizler sonucunda demografik değişkenler ile TPAB geneli ve alt boyutlarındaki ilişkilere bakılmış ve sadece anlamlı sonuçlara yer verilmiştir.

\section{Öğretmenlerin TPAB düzeyleri}

Ortaöğretim öğretmenlerinin TPAB düzeylerini gösteren puan ortalamaları ve standart sapmalar Tablo 7'de verilmiştir. 
Tablo 7. TPAB ölçek boyutlarına ilişskin puan ortalamaları ve standart sapma değerleri

\begin{tabular}{lccc}
\hline & $\mathbf{N}$ & $\overline{\mathbf{X}}$ & $\mathbf{S}$ \\
\hline AB & 436 & 4.44 & .54 \\
PABB & 436 & 4.22 & .51 \\
TB & 436 & 3.65 & .87 \\
TPABB & 436 & 4.02 & .78 \\
Tüm Ölçek & 436 & 4.10 & .53 \\
\hline
\end{tabular}

Öğretmenlerin aldıkları puan ortalamalarının değerlendirilmesinde, 1.00-1.80 aralı̆̆ı "Hiç", 1.81-2.60 aralığı "Az Düzeyde", 2.61-3.40 aralığı “Orta Düzeyde”, 3.42-4.20 aralığı "İyi Düzeyde" ve 4.21-5.00 aralığı "Çok İyi Düzeyde" șeklinde değerlendirilmiştir (Karataş, 2014). Bu değerlendirme ölçütlerine göre puan ortalamaları incelendiğinde, öğretmenlerin $A B(\bar{X}=4.44)$ ve $P A B B(\bar{X}=4.22)$ boyutlarında çok iyi düzeyde, TB $(\bar{X}=3.65)$ ve TPABB boyutu $(\bar{X}=4.02)$ ile ölçek genelinde $(\bar{X}=4.10)$ ise iyi düzeyde oldukları görülmektedir.

\section{Demografik değişkenler ile TPAB düzeyleri arasındaki ilişki}

Öğretmenlerin demografik değişkenleri ile TPAB düzeyleri arasındaki ilişkiler Tablo 8 ve Tablo 9'da gösterildiği gibi çıkmıştır.

Tablo 8. Cinsiyet, eğitim düzeyi, okul türü ve TPAB düzeyleri arasındaki ilişki

\begin{tabular}{|c|c|c|c|c|c|c|c|c|}
\hline Değişken & & & $\mathbf{N}$ & $\overline{\mathbf{X}}$ & S & sd & $\mathbf{t}$ & $\mathbf{p}$ \\
\hline \multirow[t]{4}{*}{ Cinsiyet } & $\mathrm{AB}$ & Erkek & 292 & 22.01 & 2.93 & 434 & -2.595 & $\mathrm{p}<.01^{*}$ \\
\hline & & Kadın & 144 & 22.72 & 2.21 & & & \\
\hline & TB & Erkek & 292 & 15.03 & 3.30 & 434 & 3.735 & $\mathrm{p}<.01^{*}$ \\
\hline & & Kadın & 144 & 13.72 & 3.72 & & & \\
\hline \multirow{2}{*}{$\begin{array}{l}\text { Eğitim } \\
\text { Düzeyi }\end{array}$} & $\mathrm{AB}$ & Lisans & 302 & 22.03 & 2.92 & 434 & -2.394 & $\mathrm{p}<.01^{*}$ \\
\hline & & Lisansüstü & 134 & 22.71 & 2.21 & & & \\
\hline \multirow[t]{2}{*}{ Okul türü } & TB & Devlet & 373 & 14.37 & 3.52 & 434 & -3.311 & $\mathrm{p}<.01^{*}$ \\
\hline & & Özel & 63 & 15.93 & 3.06 & & & \\
\hline
\end{tabular}

Öğretmenler arasında cinsiyet değişkende yapılan t-testi sonuçlarına göre AB faktöründe kadınlar lehine ve TB faktöründe ise erkekler lehine $(\mathrm{p}<.01)$; mesleki deneyim değişkeninde yapılan tek yönlü ANOVA testi sonuçlarına göre, $A B$ boyutunda mesleki deneyimi 16-20 yll arası deneyime sahip olanların lehine $[\mathrm{F}(4-431)=2.785, \mathrm{p}<.01]$; eğitim düzeyi değişkeninde yapılan t-testi sonuçlarına göre $\mathrm{AB}$ faktöründe lisansüstü eğitim düzeyi lehine $(\mathrm{p}<.01)$; alan değişkeninde tek yönlü ANOVA testi sonuçlarına göre AB boyutunda sosyal bilimler lehine $[\mathrm{F}(8-427)=2.443, \mathrm{p}<.01]$, TB boyutunda yabancı dil lehine $[\mathrm{F}(7-427)=2.267, \mathrm{p}<.01]$, Ölçek genelinde ise yine yabancı dil lehine $[\mathrm{F}(8-427)=2.367, \mathrm{p}<.01]$; görev yapılan okul türü değişkeninde yapılan t-testi sonuçlarına göre TB faktöründe özel okullar lehine ( $\mathrm{p}<.01)$; görev yapılan okul kategorisi değişkeninde tek yönlü ANOVA testi sonuçlarına göre $A B$ boyutunda kız meslek lisesi lehine $[F(5-430)=3.681, p<.01]$, PABB boyutunda ise yine kiz meslek lisesi lehine $[\mathrm{F}(5-430)=4.698, \mathrm{p}<.01]$, TB boyutunda fen lisesi lehine $[F(5-430)=8.632, p<.01]$, TPABB boyutunda yine fen lisesi lehine $[F(5-430)=7.542, p<.01]$, TPAB ölçeğinin genelinde de fen lisesi lehine $[\mathrm{F}(5-430)=8.634, \mathrm{p}<.01]$; bilgisayar kullanma yeterliliği algısı değişkeninde yapılan tek yönlü ANOVA testi sonuçlarına göre $\mathrm{TB}[\mathrm{F}(3-432)=14.863, \mathrm{p}<.01]$, TPABВ[F(3-432)=4.642, p<.01] ve Tüm Ölçekte $[\mathrm{F}(3-432)=6.865, \mathrm{p}<.01]$ yüksek yeterlilik lehine anlamlı farklar elde edilmiştir. 
Tablo 9. Mesleki deneyim, alan, okul kategorisi, bilgisayar kullanma yeterliliği algısı ve TPAB düzeyleri arasındaki iliski

\begin{tabular}{|c|c|c|c|c|c|c|c|}
\hline Değişken & Boyut & $\begin{array}{l}\text { Varyansın } \\
\text { Kaynağı }\end{array}$ & $\begin{array}{l}\text { Kareler } \\
\text { Toplamı }\end{array}$ & sd & $\begin{array}{l}\text { Kareler } \\
\text { ortalaması }\end{array}$ & $\mathbf{F}$ & $\mathbf{p}$ \\
\hline \multirow{3}{*}{$\begin{array}{l}\text { Mesleki } \\
\text { Deneyim }\end{array}$} & \multirow[t]{3}{*}{$\mathrm{AB}$} & G.Arası & 82.155 & 4 & 20.539 & \multirow[t]{3}{*}{2.785} & \multirow[t]{3}{*}{$\mathrm{p}<.01^{*}$} \\
\hline & & G.İçi & 3179.091 & 431 & 7.376 & & \\
\hline & & Toplam & 3261.247 & 435 & & & \\
\hline \multirow[t]{9}{*}{ Alan } & \multirow[t]{3}{*}{$\mathrm{AB}$} & G.Arası & 142.724 & 8 & 17.840 & \multirow[t]{3}{*}{2.443} & \multirow[t]{3}{*}{$\mathrm{p}<.01^{*}$} \\
\hline & & G.İçi & 3118.524 & 427 & 7.303 & & \\
\hline & & Toplam & 3261.248 & 435 & & & \\
\hline & \multirow[t]{3}{*}{ TB } & G.Arası & 217.220 & 8 & 27.153 & \multirow[t]{3}{*}{2.267} & \multirow[t]{3}{*}{$\mathrm{p}<.01^{*}$} \\
\hline & & G.İçi & 5113.339 & 427 & 11.975 & & \\
\hline & & Toplam & 5330.560 & 435 & & & \\
\hline & \multirow[t]{3}{*}{ Tüm Ölçek } & G.Arası & 4746.516 & 8 & 593.314 & \multirow[t]{3}{*}{2.367} & \multirow[t]{3}{*}{$\mathrm{p}<.01^{*}$} \\
\hline & & G.İçi & 107011.044 & 427 & 250.611 & & \\
\hline & & Toplam & 111757.560 & 435 & & & \\
\hline \multirow{15}{*}{$\begin{array}{l}\text { Okul } \\
\text { Kategorisi }\end{array}$} & \multirow[t]{3}{*}{$\mathrm{AB}$} & G.Arası & 133.856 & 5 & 26.771 & \multirow[t]{3}{*}{3.681} & \multirow[t]{3}{*}{$\mathrm{p}<.01^{*}$} \\
\hline & & G.İçi & 3127.392 & 430 & 7.273 & & \\
\hline & & Toplam & 3261.248 & 435 & & & \\
\hline & \multirow[t]{3}{*}{ PABB } & G.Arası & 480.740 & 5 & 96.148 & \multirow[t]{3}{*}{4.698} & \multirow[t]{3}{*}{$\mathrm{p}<.01^{*}$} \\
\hline & & G.İçi & 8800.239 & 430 & 20.466 & & \\
\hline & & Toplam & 9280.979 & 435 & & & \\
\hline & \multirow[t]{3}{*}{ TB } & G.Arası & 486.250 & 5 & 97.250 & \multirow[t]{3}{*}{8.632} & \multirow[t]{3}{*}{$\mathrm{p}<.01^{*}$} \\
\hline & & G.İçi & 4844.310 & 430 & 11.266 & & \\
\hline & & Toplam & 5330.560 & 435 & & & \\
\hline & \multirow{3}{*}{ TPABB } & G.Arası & 3088.641 & 5 & 617.728 & \multirow[t]{3}{*}{7.542} & \multirow[t]{3}{*}{$\mathrm{p}<.01^{*}$} \\
\hline & & G.İçi & 35219.072 & 430 & 81.905 & & \\
\hline & & Toplam & 38307.713 & 435 & & & \\
\hline & Tüm Ölçek & G.Arası & 10196.799 & 5 & 2039.360 & 8.634 & $\mathrm{p}<.01^{*}$ \\
\hline & & G.İci & 101560.761 & 430 & 236.188 & & \\
\hline & & Toplam & 111757.560 & 435 & & & \\
\hline Bilgisayar & TB & G.Arası & 498.725 & 3 & 166.242 & 14.863 & $\mathrm{p}<.01^{*}$ \\
\hline Kullanma & & G.İçi & 4831.835 & 432 & 11.185 & & \\
\hline Yeterliliği & & Toplam & 5330.560 & 435 & & & \\
\hline AlgıSı & TPABB & G.Arası & 1196.239 & 3 & 398.746 & 4.642 & $\mathrm{p}<.01^{*}$ \\
\hline & & G.İçi & 37111.474 & 432 & 85.906 & & \\
\hline & & Toplam & 38307.713 & 435 & & & \\
\hline & Tüm Ölçek & G.Arası & 5085.751 & 3 & 1695.250 & 6.865 & $\mathrm{p}<.01^{*}$ \\
\hline & & G.İçi & 106671.808 & 432 & 246.925 & & \\
\hline & & Toplam & 111757.560 & 435 & & & \\
\hline
\end{tabular}

\section{Etkileşimli tahta bulunma durumuna göre TPAB düzeyleri}

Öğretmenlerinin TPAB düzeylerinin okullarında etkileşimli tahta bulunma durumlarına göre incelenmesi amacıyla yapılan bağımsız örneklem t-testi sonuçları Tablo 10'daki gibi olmuştur. Buna göre, AB, TB, TPABB boyutları ve tüm ölçekte okullarında etkileşimli tahta bulunan öğretmenler lehine anlamlı fark tespit edilmiştir $(\mathrm{p}<.01)$, PABB boyutunda ise anlamlı bir fark olmadığı görülmüştür ( $p>.05)$. 
Tablo 10. Etkileşimli tahta bulunma durumuna göre TPAB düzeyleri

\begin{tabular}{llllllll}
\hline & & $\mathbf{N}$ & $\overline{\mathbf{X}}$ & $\mathbf{S}$ & $\mathbf{s d}$ & $\mathbf{t}$ & $\mathbf{p}$ \\
\hline $\mathrm{AB}$ & Evet & 348 & 22.38 & 2.77 & 434 & 2.135 & $\mathrm{p}<.01^{*}$ \\
& Hayır & 88 & 21.69 & 2.52 & & & \\
\hline PABB & Evet & 348 & 38.07 & 4.61 & 434 & .707 & .480 \\
& Hayır & 88 & 37.68 & 4.65 & & & \\
\hline TB & Evet & 348 & 14.94 & 3.19 & 434 & 4.126 & $\mathrm{p}<.01^{*}$ \\
& Hayır & 88 & 13.25 & 4.26 & & & \\
\hline TPABB & Evet & 348 & 49.49 & 7.66 & 434 & 5.650 & $\mathrm{p}<.01^{*}$ \\
& Hayır & 88 & 43.37 & 13.25 & & & \\
\hline Tüm Ölçek & Evet & 348 & 124.89 & 14.23 & 434 & 4.766 & $\mathrm{p}<.01^{*}$ \\
& Hayır & 88 & 116.00 & 20.30 & & & \\
\hline
\end{tabular}

Kurs alma durumuna göre TPAB düzeyleri

Öğretmenlerinin ТРAB düzeylerinin etkileşimli tahta ve diğer öğretim teknolojileri kursunu alıp almama durumlarına göre incelenmesi amacıyla yapılan ilişkisiz örneklemler t-testi sonuçları Tablo 11'de verilmiştir. Bu sonuçlara göre TB, TPABB boyutları ve tüm ölçekte, etkileşimli tahta kursuna katılan öğretmenler lehine anlamlı fark olduğu $(\mathrm{p}<.01)$, AB ve PABB boyutlarında ise anlamlı bir fark olmadığı görülmüştür ( $p>.05)$.

Tablo 11. Kurs alma durumuna göre TPAB düzeyleri

\begin{tabular}{|c|c|c|c|c|c|c|c|}
\hline & & $\mathbf{N}$ & $\overline{\mathbf{X}}$ & $S$ & sd & $\mathbf{t}$ & $\mathbf{p}$ \\
\hline \multirow{2}{*}{$\overline{\mathrm{AB}}$} & Evet & 235 & 22.46 & 2.56 & 434 & 1.822 & .069 \\
\hline & Hayır & 201 & 21.99 & 2.91 & & & \\
\hline \multirow[t]{2}{*}{ PABB } & Evet & 235 & 38.23 & 4.54 & 434 & 1.199 & .231 \\
\hline & Hayır & 201 & 37.70 & 4.69 & & & \\
\hline \multirow[t]{2}{*}{ TB } & Evet & 235 & 15.18 & 3.12 & 434 & 3.841 & $\mathrm{p}<.01^{*}$ \\
\hline & Hayır & 201 & 13.91 & 3.78 & & & \\
\hline \multirow[t]{2}{*}{ TPABB } & Evet & 235 & 49.87 & 8.04 & 434 & 3.946 & $\mathrm{p}<.01^{*}$ \\
\hline & Hayır & 201 & 46.37 & 10.45 & & & \\
\hline \multirow[t]{2}{*}{ Tüm Ölçek } & Evet & 235 & 125.76 & 14.92 & 434 & 3.812 & $\mathrm{p}<.01^{*}$ \\
\hline & Hayır & 201 & 119.98 & 16.73 & & & \\
\hline
\end{tabular}
düzeyleri

Etkileşimli tahta ve diğer öğretim teknolojilerini kullanma yeterliliği algısına göre TPAB

Ortaöğretim öğretmenlerinin TPAB düzeylerinin etkileşimli tahta kullanma yeterliliği algısına göre değişme durumunu görmek için yapılan tek yönlü ANOVA testi sonuçlarına göre, $A B[F(2-$ $433)=8.360, \mathrm{p}<.01], \mathrm{PABB}[\mathrm{F}(2-433)=6.649, \mathrm{p}<.01], \mathrm{TB}[\mathrm{F}(2-433)=71.980, \mathrm{p}<.01], \mathrm{TPABB}[\mathrm{F}(2-$ $433)=38.448, \mathrm{p}<.01]$ boyutlarında ve tüm ölçek genelinde $[\mathrm{F}(3-432)=45.176, \mathrm{p}<.01]$ kullanma yeterlilikleri yüksek olanlar lehine anlamlı farklar tespit edimiştir. 
Tablo 12. Etkileşimli tahta kullanma yeterliliği algısına göre TPAB düzeyleri

\begin{tabular}{|c|c|c|c|c|c|c|}
\hline & $\begin{array}{l}\text { Varyans } \\
\text { Kaynağı }\end{array}$ & $\begin{array}{l}\text { Kareler } \\
\text { Toplamı }\end{array}$ & Sd & $\begin{array}{l}\text { Kareler } \\
\text { Ortalaması }\end{array}$ & $\mathbf{F}$ & $\mathbf{p}$ \\
\hline \multirow[t]{3}{*}{$\overline{\mathrm{AB}}$} & G.Arası & 121.256 & 2 & 60.628 & 8.360 & $\mathrm{p}<.01^{*}$ \\
\hline & G.İंçi & 3139.992 & 433 & 7.252 & & \\
\hline & Toplam & 3261.248 & 435 & & & \\
\hline \multirow[t]{3}{*}{ PABB } & G.Arası & 276.543 & 2 & 138.271 & 6.649 & $\mathrm{p}<.01^{*}$ \\
\hline & G.İçi & 9004.437 & 433 & 20.795 & & \\
\hline & Toplam & 9280.979 & 435 & & & \\
\hline \multirow{3}{*}{ TB } & G.Arası & 1330.058 & 2 & 665.029 & 71.980 & $\mathrm{p}<.01^{*}$ \\
\hline & G.İçi & 4000.502 & 433 & 9.239 & & \\
\hline & Toplam & 5330.560 & 435 & & & \\
\hline \multirow{3}{*}{ TPABB } & G.Arası & 5777.136 & 2 & 2888.568 & 38.448 & $\mathrm{p}<.01^{*}$ \\
\hline & G.İंçi & 32530.577 & 433 & 75.128 & & \\
\hline & Toplam & 38307.713 & 435 & & & \\
\hline \multirow[t]{3}{*}{ Tüm Ölçek } & G.Arası & 19293.768 & 2 & 9646.884 & 45.176 & $\mathrm{p}<.01^{*}$ \\
\hline & G.İçi & 92463.791 & 433 & 213.542 & & \\
\hline & Toplam & 111757.560 & 435 & & & \\
\hline
\end{tabular}

Öğretmenlerin TPAB düzeylerinin diğer öğretim teknolojilerini kullanma yeterliliği algılarına göre değişimlerine ilişkin tek yönlü ANOVA sonuçları Tablo 13'de verildiği gibidir. Bu sonuçlara göre $\mathrm{AB}[\mathrm{F}(3-432)=4.944, \mathrm{p}<.01], \quad \mathrm{PABB}[\mathrm{F}(3-432)=5.190, \mathrm{p}<.01], \quad \mathrm{TB} \quad[\mathrm{F}(3-432)=32.495, \quad \mathrm{p}<.01]$, TPABB[F(3-432)=14.122, p<.01] boyutlarında ve tüm ölçekte[F(3-432)=18.749, p<.01] kullanma yeterliliği yüksek olanlar lehine anlamlı farklılıkların olduğu görülmüştür.

Tablo 13. Diğer öğretim teknolojilerini kullanma yeterliliği algılarına göre TPAB düzeyleri

\begin{tabular}{|c|c|c|c|c|c|c|}
\hline & $\begin{array}{l}\text { Varyans } \\
\text { Kaynağı }\end{array}$ & $\begin{array}{l}\text { Kareler } \\
\text { Toplamı }\end{array}$ & Sd & $\begin{array}{l}\text { Kareler } \\
\text { Ortalaması }\end{array}$ & $\mathbf{F}$ & $\mathbf{p}$ \\
\hline $\mathrm{AB}$ & $\begin{array}{l}\text { G.Arası } \\
\text { G.İçi } \\
\text { Toplam }\end{array}$ & $\begin{array}{l}108.262 \\
3152.986 \\
3261.248\end{array}$ & $\begin{array}{l}3 \\
432 \\
435\end{array}$ & $\begin{array}{l}36.087 \\
7.299\end{array}$ & 4.944 & $\mathrm{p}<.01^{*}$ \\
\hline PABB & $\begin{array}{l}\text { G.Arası } \\
\text { G.İçi } \\
\text { Toplam }\end{array}$ & $\begin{array}{l}322.879 \\
8958.100 \\
9280.979\end{array}$ & $\begin{array}{l}3 \\
432 \\
435 \\
\end{array}$ & $\begin{array}{l}107.626 \\
20.736\end{array}$ & 5.190 & $\mathrm{p}<.01^{*}$ \\
\hline TB & $\begin{array}{l}\text { G.Arası } \\
\text { G.İçi } \\
\text { Toplam }\end{array}$ & $\begin{array}{l}981.430 \\
4349.130 \\
5330.560\end{array}$ & $\begin{array}{l}3 \\
432 \\
435 \\
\end{array}$ & $\begin{array}{l}327.143 \\
10.067\end{array}$ & 32.495 & $\mathrm{p}<.01^{*}$ \\
\hline TPABB & $\begin{array}{l}\text { G.Arası } \\
\text { G.İçi } \\
\text { Toplam }\end{array}$ & $\begin{array}{l}3421.329 \\
34886.384 \\
38307.713\end{array}$ & $\begin{array}{l}3 \\
432 \\
435 \\
\end{array}$ & $\begin{array}{l}1140.443 \\
80.756\end{array}$ & 14.122 & $\mathrm{p}<.01^{*}$ \\
\hline Tüm Ölçek & $\begin{array}{l}\text { G.Arası } \\
\text { G.İçi } \\
\text { Toplam }\end{array}$ & $\begin{array}{l}12874.917 \\
98882.642 \\
111757.560\end{array}$ & $\begin{array}{l}3 \\
432 \\
435\end{array}$ & $\begin{array}{l}4291.639 \\
228.895\end{array}$ & 18.749 & $\mathrm{p}<.01^{*}$ \\
\hline
\end{tabular}

Etkileşimli tahta ve diğer öğretim teknolojilerini kullanma sıklı̆̆ına göre TPAB düzeyleri

Ortaöğretim öğretmenlerinin TPAB düzeylerinin derslerinde etkileşimli tahta kullanma sıklığına göre nasıl değiștiğini görmek için yapılan tek yönlü ANOVA testi sonuçları Tablo 14'teki gibi çıkmıştır. Buna göre, TB[F(4-431)=14.667, p<.01], TPABB[F(4-431)=17.105, p<.01] boyutları ve tüm ölçekte[F(4-431)=12.963, $\mathrm{p}<.01]$ derslerinde etkileşimli tahtayı daha sık kullananlar lehine anlamlı farklılıklar olduğu gözlenmiştir. 
Tablo 14. Etkileşimli tahta kullanma slklı̆̆ına göre TPAB düzeyleri

\begin{tabular}{lllllll}
\hline & $\begin{array}{l}\text { Varyans } \\
\text { Kaynağı }\end{array}$ & Kareler Toplamı & Sd & $\begin{array}{l}\text { Kareler } \\
\text { Ortalaması }\end{array}$ & F & $\mathbf{p}$ \\
\hline TB & G.Arası & 638.667 & 4 & 159.667 & 14.667 & $\mathrm{p}<.01^{*}$ \\
& G.İçi & 4691.892 & 431 & 10.886 & & \\
\hline TPABB & Goplam & 5330.560 & 435 & & & \\
& G.Arası & 5248.208 & 4 & 1312.052 & 17.105 & $\mathrm{p}<.01^{*}$ \\
& G.İçi & 33059.505 & 431 & 76.704 & & \\
\hline Tüm Ölçek & Toplam & 38307.713 & 435 & & 12.963 & $\mathrm{p}<.01^{*}$ \\
& G.Arası & 12000.963 & 4 & 3000.241 & & \\
& G.İçi & 99756.597 & 431 & 231.454 & & \\
& Toplam & 111757.560 & 435 & & & \\
\end{tabular}

Öğretmenlerin TPAB düzeylerinin diğer öğretim teknolojilerini kullanma sıklığına göre farklılașması da benzer șekilde çıkmıștır. Tablo 15'deki ANOVA sonuçlarına göre TB[F(4431)=14.665, p<.01], TPABB[F(4-431)=17.182, p<.01] boyutları ve tüm ölçekte[F(4-431)=12.853, $\mathrm{p}<.01]$ diğer öğretim teknolojilerini daha sık kullananlar lehine anlamlı farklılıklar ortaya çıkmıştır.

Tablo 15. Diğer öğretim teknolojilerini kullanma sıklı̆̆ına göre TPAB düzeyleri

\begin{tabular}{lllllll}
\hline & $\begin{array}{l}\text { Varyans } \\
\text { Kaynağı }\end{array}$ & $\begin{array}{l}\text { Kareler } \\
\text { Toplamı }\end{array}$ & Sd & $\begin{array}{l}\text { Kareler } \\
\text { Ortalamas }\end{array}$ & $\mathbf{F}$ & $\mathbf{p}$ \\
\hline TB & G.Arası & 638.604 & 4 & 159.651 & 14.665 & $\mathrm{p}<.01^{*}$ \\
& G.İçi & 4691.956 & 431 & 10.886 & & \\
\hline TPplam & 5330.560 & 435 & & & \\
& G.Arası & 5268.368 & 4 & 1317.092 & 17.182 & $\mathrm{p}<.01^{*}$ \\
& G.İ́çi & 33039.344 & 431 & 76.657 & & \\
\hline Tüm Ölçek & Toplam & 38307.713 & 435 & & 12.853 & $\mathrm{p}<.01^{*}$ \\
& G.Arası & 11910.496 & 4 & 2977.624 & & \\
& G.İçi & 99847.063 & 431 & 231.664 & & \\
& Toplam & 111757.560 & 435 & & & \\
\hline
\end{tabular}

\section{Öğretmenlerin etkileșimli tahta ve diğer öğretim teknolojilerini kullanma durumları}

Öğretmenlerin kendilerini teknolojik, pedagojik ve alan bilgisi açısından nasıl tanımladıklarını öğrenmek amacıyla görüşme yöntemi ile öğretmenlerden alınan veriler ortak temalar altında kodlanmıştır. Görüşmeye katılan 12 öğretmenden 5’i (\%42) teknolojik açıdan kendini yeterli-iyi düzeyde görürken 7'si (\%58) kısmen yeterli-orta düzeyde görmektedir. Katılımcı görüşlerinden bazıları șu șekildedir:

"Kendime yetecek kadar biliyorum. Word, excel, powerpoint falan, derste kullanacak, soru hazırlayacak, sunum yapacak ve video oynatacak, ekleyecek kadar biliyorum." (Ö1)

"Kendimi teknolojiyi kullanma açısından ne çok iyi ne çok kötü, orta düzeyde görüyorum." (Ö5)

Görüşmeye katılan 12 öğretmenden 10’u (\%83) pedagojik açıdan kendini yeterli-iyi düzeyde görürken 2'si ise (\% 27) kendisini kısmen yeterli-orta düzeyde görmektedir. Katılımcı görüşlerinden bazıları şu şekildedir:

"Ben derste farklı teknikler kullanma ve sinıf yönetimi gibi şeylerde kendimi yeterli düzeyde görüyorum."(Ö5)

"Pedagojik olarak iyi olduğumu düşünüyorum. Öğrencilere disiplinden de taviz vermeden dersi sevdirmeye çalışıorum. Çünkü matematik çok da zor bir derstir. Bu zor dersi de çocuklara aktarmak için dersi bazen eğlenceli hale getirebiliyoruz. O konularda fena olmadığımı düşünüyorum." (Ö10) 
Görüşmeye katılan 12 öğretmenden 9'u (\%75) alan bilgisi yeterliliği açısından kendini yeterliiyi düzeyde görürken 3’ü (\% 25) kısmen yeterli-orta düzeyde görmektedir. Katılımcı görüşlerinden bazıları şu şekildedir:

"Alan bilgisi olarak kendimi değerlendirdiğimde ne çok iyi ne de çok kötüyüm. Ortalarda bir yerdeyim diyebilirim." (Ö2)

"Kendimi alan bilgisi düzeyinde yeterli görüyorum, konuya hâkimim, ne demek istediğimi biliyorum, ne sunmam gerektiğini çok iyi biliyorum." (Ö5)

Öğretmenlerin derslerinde etkileşimli tahta ve diğer öğretim teknolojilerini dersin hangi bölümlerinde ve hangi amaçlarla kullandıklarına yönelik elde edilen görüşme verilerine göre, öğretmenlerden 7'si (\%59) ihtiyaç duyulduğunda, 5'i (\%41) ise dersin bütününde teknoloji kullandıklarını ifade etmişlerdir. Katılımcı görüşlerinden bazıları şu şekildedir:

"Akıllı tahtayı bütün süreçte kullanıyorum. Zaten evde Starboard sayfasında ilgili konuyu hazırlıyorum. Sorularımı hazırlıyorum, flaşla akıllı tahtaya taşıyorum ve öğrencilerime içerik olarak veya görsel olarak dersimi sunuyorum. Dersin başından sonuna kadar sürekli teknolojiyi kullaniyorum." (Ö3)

"Yer yer kullanıyorum bazen de yeri geldiği zaman kullanıyorum. Dersin akışına ve konunun niteliğine bağlıdır." (Ö5)

Çalışmaya katılan öğretmenlerin derslerinde teknolojiyi en çok hangi amaçlarla kullandıkları sorusuna öğretmenlerin 8'i (\%67) konu anlatımı, 8'i (\%67) soru çözümü, 7’si (\%58) film, belgesel ve video izletme, 6'sı (\%50) çizim yapma, 6’sı (\%50) resim gösterme, 6’sı (\%50) konuyu pekiştirme, 5’i (\%42) sunum yapma, 5'i (\%42) motivasyon sağlama, 4'ü (\%33) yazı yazma, 4'ü (\%33) kalıcılık sağlama ve kavratma, 4'ü (\%33) şekil ve şema gösterme, 4'ü (\%33) Starboard kullanma, 3'ü (\%25) müzik dinletme, 3'ü (\%25) pdf dosyası kullanma, 2'si (\%17) zamandan kazanma, 2'si (\%17)konuyu zenginleștirme, 2'si (\%17) kağıt ve tonerden tasarruf etme, 2'si (\%17) animasyon gösterme, 2'si (\%17) Z-kitap kullanma, 2'si (\%17) özet ve tekrar yapma, 1'i (\%8) harita gösterme, 1'i (\%8) okuma yaptırma, 1'i (\%8) dikkat çekme ve 1'i (\%8) sınıfta hakimiyet kurma şeklinde cevap vermişlerdir. Katılımcı görüșlerinden bazıları șu șekildedir:

"Genellikle okuma yaptığımız zaman analiz kısmında, öğrencilerin dikkatini çekmek için, altını çizme oluyor ya da video izletebiliyoruz. Ya da dinleme parçaları olabiliyor. Yani her şekilde kullanabiliyoruz. Okuma, dinleme, izleme..."(Ö9)

"Genellikle konu anlatımı, soru çözme, sunum yapma ve çizim yapma amacıyla kullanıyorum. Dağılımı olan bir konuyu harita üzerinde göstermek bizim için çok önemlidir ve öğrenciye kolaylı sağllyor. Özellikle sorular üzerinde ya da konu üzerinde, harita üzerinde dağılımı olan konularda teknolojiye başvuruyorum." (Ö12)

Öğretmenlerin derslerinde çağdaş öğretim teknolojilerini içeren ve içermeyen hangi yöntem ve tekniklere başvurduklarına yönelik görüşme yöntemi ile elde edilen verilere göre, öğretmenlerin 9'u (\%75) dersi görsel-işitsel materyallerle desteklemek, 9'u (\%75) teknolojiyi öğrenciye aktif kullandırma, 6'sı (\%50) daha hızlı ve daha çok soru çözme, 5’i (\%42) ilgi çekme ve motivasyon sağlama, 5’i (\%42) sunum programı ile konu anlatma, 5'i (\%42) teknoloji kullanarak konuyu örneklendirme ve zenginleştirme, 3'ü (\%25) akıllı tahtada bireysel ve toplu değerlendirme yapma, 3'ü (\%25) teknoloji ile konuyu somutlaştırma, 2'si (\%17) teknoloji kullanımı ile sınıfın geneline hitap etme, 2'si (\%17) teknoloji ile konu tekrarı ve özetini yapma ve 1'i (\%8) teknoloji ile ön bilgi sunma şeklinde derslerinde çağdaş öğretim teknolojilerini içeren yöntem ve tekniklere başvurduklarını belirtmișlerdir. Katılımcı görüșlerinden bazıları șu șekildedir:

"Öğrencilere tahtada soru çözdürerek onları da derse katıyorum. Soruları daha çok konuyu pekiştirmek için kullanıyorum. Değerlendirme kısmında kendi dağıttığım quizler oluyor, test yöntemlerine başvuruyoruz." (Ö2)

“Öğrenciye mesela konu veriyoruz önceden çalışlyor ve akıllı tahta üzerinde anlatmak istiyorsa izin veriyoruz. Hazırladığımız sunulara bağlı olarak hem konuyu pekiştirme hem de dersin 
sonunda genel bir özet ve tekrar için konu ile ilgili etkileşimli tahtadan konu tarama testleri de yapıyoruz." (0̈7)

Öğretmenlerin 9’u (\%75) soru cevap yapma, 7'si (\%58) proje-performans ödevi verme, 6'si (\%50) sunuş yoluyla düz anlatım yapma, 5’i (\%42) tartışma yaptırma, 4'ü (\%33) öğrenciye buldurma, 2'si (\%17) canlı ders materyali kullanma, 2'si (\%17) öğrenciyi sürece katma, 2'si (\%17) küme çalışması yaptırma, 2'si (\%17) geçmiş bilgilerle ilişki kurma, 1'i (\%8) soru ile merak uyandırma, 1'i (\%8) soru ile hazır bulunuşluk ölçme, 1'i (\%8) normal tahtada ön bilgi verme, 1'i (\%8) ipucu verme ve 1'i (\%8) de dönüt alma şeklinde derslerinde çağdaş öğretim teknolojilerini içermeyen yöntem ve tekniklere başvurduklarını belirtmişlerdir. Katılımcı görüşlerinden bazıları şu şekildedir:

“Gerektiğinde küme çalışması yapabiliyoruz. Diyelim ki Tanzimat fermanının Osmanlı'ya etkisini anlattı̆ımızda, olumlu ya da olumsuz etkileri olduğu söylenilir. İşte bunu öğrencileri iki guruba ayırarak ve münazara yaptırarak olumlu ve olumsuz etkileri diye tartışmaya açıp ögrencilerin daha iyi öğrenmelerini sağllyoruz yani. Dersi yeri geldiğinde öğretmen merkezli yeri geldiğinde de öğrenci merkezli işliyoruz. Dersin gidişatına göre hangisi gerekiyorsa onu kullanıyoruz."(Ö3)

“Genellikle dersin ilk etabında sunum oluyor. Böyle bir düz anlatım yöntemim var. Düz anlatımı genellikle kara tahtada yapıyoruz. Ama bu bir önbilgi ve ön hazırlık aşaması için. Yani öğrencilerin hazır bulunuşluk seviyesini ölçmek için. İlgi merak uyandırmaya çalışıorum. Ya da kısa sorularla soru soruyorum, cevap allyorum hatta buldurmaya çalışlyorum."(Ö5)

\section{Öğretmenlerin etkileşimli tahta ve diğer öğretim teknolojilerini kullanımlarına ilişkin yeterlilik algıları, olumlu- olumsuz görüşleri ve karşılaştıkları engeller}

Görüşme yapılan öğretmenlere göre günümüz öğretmenlerinin hangi yeterliliklere sahip olmaları gerektiği sorulduğunda, öğretmenlerin tamamı (\%100), öğretmenlerin pedagojik, alan bilgisi ve teknolojik yeterliliklere sahip olmasını gerekli görmüştür. Ayrıca 10’u (\%83) öğrenci ile olumlu iletişim, 8'i (\%67) etkili sınıf yönetimi, 3'ü (\%25) günceli takip etme ve kendini yenileme, 3'ü (\%25) karakterli ve örnek olma, 2'si (\%17) farklı alanlara da hakim olma, 2'si (\%17) tutarlı olma ve 2'si (\%17) empati kurabilme yeterliliklerinin de öğretmenlerde olması gerektiğini düşünmektedir. Katılımcı görüşlerinden bazıları şu şekildedir:

"Ben pedagojik yeterliliğe daha fazla önem veriyorum. Çünkü kendimizi değerlendirecek olursak hangi ders yeterince aklımızda kalmış veya kazınmıştır? Pedagoji biraz daha kalıcı oluyor, ondan sonra çocuğun gönlünü, kalbini, ilgisini çektikten sonra ders işlemesi ve kavratması da daha kolay oluyor. O yüzden siralamaya göre birinci pedagoji, ikinci alan ve üçüncü olarak teknoloji diyorum." (Ö1)

“Öğretmenin bir kere pedagojik olarak çok iyi bir hâkimiyetinin olması gerekir. Sadece bilmesi gerekmiyor bunu öğretim sürecinde de davranışa dökmesi gerekiyor. İkincisi alan bilgisine müthiş bir derecede hâkim olması gerekiyor. Üçüncüsü yaşadığı çağa da tanık olması gerekiyor. Çünkü bilgiyi pedagojik formasyonla birleștirip çağın da içinde bulunduğu durumu değerlendirerek konuyu o şekilde anlatırsın. Kültürü bilmesi somutlaştırması anlamına geliyor, pedagoji bilmesi öğrenci ile iletişim kurmasını sağlar. Alanı iyi bilmesi ise öğrencinin gözünde güven sağlar."(Ö5)

Öğretmenlerin üniversite öğrenimleri sırasında verilen eğitimlerin teknolojik, pedagojik ve alan bilgisi yeterliliklerini kazandırması açısından görüşlerine bakıldığında, tamamı (\%100) teknolojik açıdan yetersiz, 9'u (\%75) pedagojik açıdan yetersiz, 7'si (\%58) alan bilgisi açısından yetersiz, 3'ü (\%25) alan bilgisi açısından kısmen yeterli, 2'si (\%17) alan bilgisi açısından yeterli, 2'si (\%17) pedagoji açıdan yeterli ve 1'i (\%8) de pedagojik açıdan kısmen yeterli görmüştür. Katılımcı görüşlerinden bazıları şu şekildedir:

"Pedagojik formasyon derslerini gördük ama bunun havada kalmış dersler olduğunu söyleyebilirim. Derslerin çoğu teorikti ve sana bir şey katmıyor zaten. Teknolojik olarak da pek faydalandığımızı söyleyemiyoruz. Alan olarak da lise öğretmeni olduktan sonra kesinlikle bizim üniversitede öğrendiğimiz birçok dersin lisede hiçbir anlam ifade etmediğini gördük. Pratikte bir karşılığı olmadığını söyleyebilirim." (Ö2) 
"Üniversitenin teknolojik olarak bir katkısı olmadı, pedagojik olarak da kısmen katkısı oldu. Bir öğretmen göreve bașlarken bazı șeyleri görüyor, bazı șeyleri öğreniyor. Yani üniversitede ne kadar da bahsedilse ve ne kadar anlatılsa da insan yaşayarak öğreniyor. Bir öğretmen de mesleğe bașlarken bazı șeyleri mesleği ile birlikte kavrıyor, öğreniyor ve tecrübe ediniyor." (Ö4)

Öğretmenlerin 7'si (\%58) hizmet-içi eğitim kurslarını yeterlilikleri karşılama açısından yetersiz, 4'ü (\%33) kısmen yeterli, 1'i (\%8) ise yeterli görmüștür. Katılımcı görüșlerinden bazıları șu şekildedir:

"Ben hizmet içi eğitim kurslarına katıldım fakat kursun bana bir șey kattığını kesinlikle düşünmüyorum. Kursların çoğu sadece kâğıt üzerinde veriliyormuş gibi bir izlenim edindim. Akıllı tahta bizim okula geldiğinde de bunu yaşadık. Kurs bir iki gün sürdü ve öğretmen kendi kendine anlatmış gibi oldu. Herhangi bir teknolojik aracı kendiniz birebir kullanmazsanız zor öğrenilir diye düşünüyorum."(Ö2)

"Hizmet içi eğitimlerin faydası oldu ama çok fazla da olmuyor. Hizmet içi eğitim olsun diğerleri olsun genelde teori anlatıllyor. Pratikte bir şey olmadiğı için ben yeterli olduğunu düşünmüyorum. Mesela akıllı tahtalarla ilgili verilen kurslarda da daha çok sunum şeklinde anlatılır geçilir. Normalde daha iyi öğrenebilmemiz için bunun aktif ve pratik bir şekilde bize öğretilmesi gerekiyor. O yüzden ben yeterli olduğunu düşünmüyorum.” (Ö7)

Öğretmenlerin 9'u (\%75) kolaydan zora doğru anlatım, 7'si (\%58) konuyu orta düzeyde tutma, 6'sı (\%50) hazır bulunuşluklarını dikkate alma, 5'i (\%42) ek ders yapma-ek soru çözme, 5'i (\%42) farklı yöntemler kullanma, 3'ü (\%25) sınıfın genel seviyesine göre anlatma, 2'si (\%17) sorularla geri bildirim alma, 2'si (\%17) teknolojik destek alma, 2'si (\%17) öğrenciyi derse katma, 2'si (\%17) şartları göz önüne alma ve 2'si (\%17) basit bir dil kullanma şeklinde öğrencilerin bireysel farklılıklarına göre öğretim sürecini şekillendirdiğini belirtmiştir. Katılımcı görüşlerinden bazıları şu şekildedir:

"Aslında sınıfa girdiğimde en üst öğrencinin seviyesinden değil de sınıfin en diplerindeki öğrencinin de seviyesini dikkate alarak, en üst seviyedeki öğrenciyi de mă̆dur etmeden konuyu işliyoruz. Hepsini mağdur etmemek için öğrencilerin de bireysel farklılıklarını dikkate alıyorum. Özellikle sunmak istediğimi orta seviyede tutmaya çalışlyorum. Alttaki öğrenciyi de o seviyeye getirmeye çalışlyorum, en üstteki öğrenciyi de mağdur etmeden sanki farklıymış gibi orta düzeyde sunmaya çalışlyorum."(Ö5)

"Bir öğretmenin bir kere öğrencilerin çevre, sosyoekonomikyapılarını falan gözlemleyip ona göre bir yol izlemesi gerekiyor. Ben her zaman içinde bulunduğum şartlara ve imkânlara göre dersimi işlerim, ona göre de planlama yaparım." (Ö8)

Öğretmenlerin okullarında teknoloji entegrasyonu konusunda karşılaştıkları engellere ilişkin 7'si (\%58) hizmet içi eğitimlerin yetersiz oluşu, 6'sı (\%50) elektrik kesintisi, 5'i (\%42) teknik sorunlar, 5'i (\%42) öğretmenin teknolojik bilgi yetersizliği, 4'ü (\%33) fiziksel hasar, 4'ü (\%33) salt teknoloji kullanımı, 3'ü (\%25) öğrencilerin sıkılması, 2'si (\%17) amacı dışında kullanım, 2'si (\%17) internet olmaması ve 1'i (\%8) teknolojik cihaz yetersizliği şeklinde görüş belirtmişlerdir. Katılımcı görüşlerinden bazıları şu şekildedir:

"Etkileşimli tahtalarla yalnızca sunup yapıp görselliği işin içine katmadan, ya da öğrenciyi de derse katmadan kullandığınızda öğrenciler sıkılabiliyor. Etkileşimli tahta sıkıcı bir araç haline dönüşebiliyor ve sürekli kullanımı monoton bir ders yaratabiliyor. Bir de elektrikler gidince hayat duruyor. Jeneratör çalıştırılıp elektrikler gittiğinde direk devreye girerse iyi olur."(Ö3)

"Genel olarak hepimizin sıkıntısı teknolojik olarak yeterli bilgiye sahip değiliz. Hizmet içi pratik yetersizliği var. Elbette ki akıllı tahta verimi arttırıyor ama sürekli olarak kullanıldığı zaman bence öğrencinin dikkati de dağıllyor. Öğrenci yeteri kadar güdülenemiyor. Yeri geldiğinde bence diğer normal tahtaların da kullanılması gerekir. En azından öğrencilerin güdülenmesini sağlayabilmek ya da dikkatlerini toplayabilmek için diğer tahtaları da kullanmak gerektiğini düşünüyorum." (Ö7) 


\section{SONUÇ ve TARTIŞMA}

$\mathrm{Bu}$ araştırmada, ortaöğretim öğretmenlerinin $\mathrm{TPAB}$ düzeyleri, öğretmenlerin genel demografik özelliklerine ve etkileşimli tahta ve diğer öğretim teknolojilerini kullanma durumlarına göre incelenmiștir. Öğretmenlerden TPAB ölçeği ile elde edilen verilerin analizine göre, ölçeğin tüm alt boyutları ve ölçek genelinde öğretmenlerin puan ortalamalarının iyi düzey ve üzerinde çıkmış olması ortaöğretim öğretmenlerinin genel olarak TPAB açısından kendilerini yeterli düzeyde gördüklerini göstermektedir. TB boyutunda iyi düzeyde olmalarına rağmen puan ortalamasının diğer boyutlara göre daha düşük kalmış olması ise dikkat çekicidir. Bunun sebebi olarak hizmet içi eğitimlerin yetersiz yönleri, teknik sorunlar ve öğretmenin teknolojik bilgi yetersizliği gibi nedenler bașta olmak üzere teknoloji entegrasyonu konusunda karşılașllan engeller gösterilmiștir. Öğretmenlerin \%67'sinin etkileşimli tahtayı ve \%71'inin diğer öğretim teknolojilerini dersleri için gerekli görmeleri, teknolojik yeterliliklerinin biraz düşük olmasına rağmen teknolojiye mesafeli durmadıklarını ve teknoloji kullanımından kaçınmadıklarını da göstermesi açısından önem taşımaktadır. TB boyutundaki yeterliliğin diğer boyutlara göre daha düşük çıkması başka çalışmalarda da karşılaşılan bir sonuç olmuştur (Bulut, 2012; Karataş, 2014; Z.Kaya, 2011; Semiz, 2011; Bal ve Karademir, 2013; Archambault ve Crippen, 2009).

TPAB düzeylerinin cinsiyet değişkenine göre incelenmesi sonucu, $A B$ boyutunda çıkan sonuç Avcı (2014) ve Karataş (2014)'ın çalışmalarının aksine kadınlar lehine çıkmıștır. TB boyutunda ise diğer bazı çalışmalarda olduğu gibi (Avcı, 2014; Bulut, 2012; Bal ve Karademir, 2013) erkekler lehine anlamlı bir farklılık görülmüştür. Ayrıca çalıșmada öğretmenlerin genel TPAB düzeylerinin cinsiyete göre farklılık göstermemesi ise başka çalışma sonuçları (Bulut, 2012; Gömleksiz ve Fidan, 2013; Jang ve Tsai, 2012; Karakaya, 2013; Mutluoğlu, 2012; Öztürk, 2013; Şimşek vd., 2013; Z.Kaya vd., 2011) ile de paralellik göstermektedir. Yaş değişkenine göre tüm alt boyutlarda ve TPAB ölçeğinin genelinde yaşa bağlı anlamlı bir farklılık olmadığı sonucu Burmabıyık (2014) ve Sabo ve Archambault'un (2012) araştırma sonuçları ile benzerlik göstermektedir. Bazı çalışmalarda ise TPAB düzeylerinin yaşı daha düşük olan katılımcıların lehine çıktığı görülmüştür (Lee ve Tsai, 2010; Şimşek vd., 2013). Karakaya (2013) ve Lee ve Tsai'nin (2010) çalışmalarında olduğu gibi bu çalışmada da AB boyutunda mesleki deneyimi yüksek olan öğretmenlerin lehine anlamlı farklılık çıkmıştır. Ancak alanyazına bakıldığında mesleki deneyimin özellikle teknoloji bilgisi ve bu bilgi ile ilişkili boyutlarda bu çalışma ile çelişen sonuçlara da rastlanmaktadır (Avcl, 2014; Bal ve Karademir, 2013; Karakaya, 2013; Mutluoğlu, 2012). Eğitim düzeyi değişkeninde ise Bal ve Karademir'in (2013) çalışmaları ile paralel şekilde $\mathrm{AB}$ boyutunda lisansüstü mezunlarının lehine anlamlı farklar elde edilmiştir. Alan boyutunda çıkan anlamları farkların alanyazındaki bazı çalışmalarla (Jang ve Tsai, 2012; Burmabıyık, 2014) çelişmesinin farklı demografik özellikteki örneklem gruplar üzerinde çalışılmasından kaynaklandığı düşünülmektedir. Mezun olunan fakülte türüne göre ölçeğin tüm alt boyutlarında ve TPAB ölçek genelinde istatistiksel olarak anlamlı bir farklılık bulunmaması Karataş (2014) ve Burmabıyık'ın (2014) çalışma sonuçları ile benzerlik göstermektedir. Öğretmenlerle yapılan görüşmelerden elde edilen nitel verilere göre öğretmenlerin mezun oldukları fakülteler farklı olsa da pedagojik formasyon alma ve hizmet içi eğitim alma bakımından ortak süreçlerden geçtiklerini ifade etmiş olmaları fakülte türüne göre anlamlı farklılık oluşmamasını desteklemektedir. Okul türü değişkeni açısından TB boyutunda özel liseler lehine anlamlı fark çıkması, bu liselerde teknolojik alt yapı ve teknik desteğin daha kaliteli olması, vizyon olarak teknoloji destekli eğitimi daha çok benimsemiş olmaları ve FATïH projesi ile devlet liselerine etkileşimli tahta ve diğer öğretim teknolojilerinin entegrasyonundan daha önce kendi imkânları ile kurulum yapmıș olmalarının etkili olduğu düşünülmektedir. Okul kategorisine göre ölçeğin tüm alt boyutlarında ve ölçek genelinde çoğunlukla fen lisesinin daha yüksek bir puan ortalamasına sahip olması, bu okulların diğer liselere göre bilinen olumlu öğrenci profilinin yanı sıra öğretmen profili açısından da daha iyi durumda olduklarına işaret etmektedir.

Bilgisayar kullanma yeterliliği algıları açısından bakıldığında Karataş'ın (2014) çalışma sonuçları ile benzer şekilde; etkileşimli tahta ve diğer öğretim teknolojilerini kullanma yeterlilik 
algıları açısından bakıldığında ise Burmabıyık (2014) ve Kabakçı-Yurdakul'un (2011) çalışma sonuçları ile benzer şekilde yüksek yeterlilik lehine anlamlı farklılıklar görülmüştür.

$\mathrm{AB}, \mathrm{TB}, \mathrm{TPABB}$ ve TPAB ölçek genelinde okullarında etkileşimli tahta bulunan öğretmenlerin lehine anlamlı farklar ortaya çıkması, başka çalışmalarda da olduğu gibi (Jang ve Tsai, 2012; Akyüz vd., 2014; Jang, 2010) etkileşimli tahtanın varlığının öğretmenlerde TPAB yeterliliği açısından pozitif etki yarattığına işaret etmektedir.

Bazı çalışmalarda (Karakaya, 2013; Bal ve Karademir, 2013; Shin vd., 2009) TB bilgisi içeren boyutlarda hizmet içi eğitim alanlar lehine çıkan anlamlı farklılık bu çalışmada da etkileşimli tahta kullanım kursuna katılan öğretmenler lehine çıkmıştır. Ayrıca, Özgen vd.'nin (2013) çalışma sonuçları ile paralel şekilde TB içeren boyutlarda etkileşimli tahta ve diğer öğretim teknolojilerini daha sık kullanan öğretmenler lehine de anlamlı farklar oluşmuştur.

Çalıșmaya katılan öğretmenler derslerinde etkileșimli tahta ve diğer öğretim teknolojilerini en fazla derste ihtiyaç duydukları zaman kullandıklarını belirtmişlerdir. Öğretmenlerin daha az bir kısmı ise teknolojiyi dersin bütününde kullandıklarını belirtmişlerdir. Görüşme yapılan öğretmenlerin teknolojiyi daha çok konunun niteliğine, dersin akışına ve yeri geldiğinde kullandıklarını yani ihtiyaç duydukları zaman kullandıklarını ifade etmiş olmaları, derste teknoloji kullanımı konusunda bağlam bilgisinin önemine işaret etmektedir (Shulman, 1986).

Araştırmaya katılan öğretmenlerin \%80'inin okulunda etkileşimli tahta bulunmaktadır ve derslerinde etkileşimli tahtayı en çok kullanma amaçları, etkileşimli tahta ile ilgili yapılan başka çalışmalarda (Akçayır, 2011; Altınçelik, 2009; Elaziz, 2008; Erduran ve Tataroğlu, 2009; Pamuk vd., 2013; Tatlı ve E.Kılıç, 2013) elde edilen sonuçlarla parallellik göstermektedir.

Öğretmenlerin çağdaş öğretim teknolojilerini içeren yöntem ve teknikleri arasında öne çıkanlar Pamuk vd.'nin (2013) çalışması ile benzer şekilde dersi görsel ve işitsel materyallerle destekleme, teknolojiyi öğrenciye aktif kullandırma, daha hızlı ve daha çok soru çözme, ilgi çekme ve motivasyon sağlama, sunum programı ile konu anlatma ve teknoloji kullanarak konuyu örneklendirme ve zenginleştirme iken; çağdaş öğretim teknolojilerini içermeyen yöntem ve teknikler arasında öne çıkanlar ise Öztürk'ün (2004) çalışma sonuçları ile benzer şekilde soru cevap yapma, proje-performans ödevi verme, sunuş yoluyla düz anlatım yapma, tartışma yaptırma ve öğrenciye buldurma olmuştur.

Görüşmeye katılan öğretmenlerin tamamı günümüzde öğretmenlerin teknoloji, pedagoji ve alan bilgisi yeterliliklerine sahip olmaları gerektiğini belirtmişlerdir. Bu yeterliliklerin dışında öğrenci ile olumlu iletişim ve etkili sınıf yönetimi gibi yeterlilikler de öğretmenlerin çoğu tarafından vurgulanmıştır. Görüşme yapılan öğretmenlerin ifade ettiği bu yeterliliklere ISTE (2008) ve ÖYEGM (2006) tarafından belirtilen öğretmen yeterlilikleri içinde de yer verilmiştir. Öğretmenlerin aldıkları üniversite eğitimlerini öğretmen yeterliliklerini kazandırma açısından değerlendirmeleri istendiğinde ise, görüşme yapılan öğretmenlerin tamamı teknolojik bilgi yeterliliği açısından, çoğunluğu ise pedagojik ve alan bilgisi yeterliliğini kazandırma açısından üniversite eğitimlerinin yetersiz kaldığını ifade etmişlerdir. Ayrıca katılımcıların bir kısmı pedagojik bilgi kazandırmaya yönelik pedagojik formasyon derslerinin havada kalmış ve uygulama içermeyen dersler olduğunu belirtmiştir. Alan bilgisi açısından da üniversitede öğretilen bilgilerin girdikleri derslerde kullanılamadığı ve görev yaptıkları okullarda pratik bir karşılığı olmayan konular içerdiği vurgulanmıştır. Üniversite/öğretmenlik eğitiminin öğretmenler için gerekli yeterlilikleri kazandırma konusunda eksik kaldığı başka çalışmalarda da vurgulanmıştır (Semiz, 2011; Şimşek vd., 2013). Görüşme yapılan öğretmenlerin çoğu aldıkları hizmet içi eğitimlerin de teknolojik, pedagojik ve alan bilgisi yeterliliklerini kazandırma açısından yetersiz kaldığını ifade etmişlerdir. Hizmetiçi eğitimlere ilişkin bu algıları başka çalışma sonuçları ile de (Karakaya, 2013; Tatlı ve E.Kılıç, 2013; Pamuk vd., 2013) benzerlik taşımaktadır.

Öğretmenler en fazla kolaydan zora doğru anlatım, konuyu orta düzeyde tutma, öğrencilerin hazır bulunuşluklarını dikkate alma, ek ders yapma, ek soru çözme ve farklı yöntemler kullanma şeklinde öğrencilerin bireysel farklılıklarına göre öğretim süreçlerini şekillendirdiklerini ifade 
etmişlerdir. Adıgüzel ve Yüksel (2012) ile Pamuk vd. (2012) de çalışmalarında öğrencilerin bireysel farklılıkları ve ortam şartlarının dikkate alınmasına vurgu yapmışlardır.

Teknoloji entegrasyonu konusunda öğretmenlerin okullarında karşılaştıkları engeller arasında öne çlkanlar, hizmet içi eğitimin yetersiz oluşu, elektrik kesintisi, teknik sorunlar, öğretmenin teknolojik bilgi yetersizliği, fiziksel hasar ve salt teknoloji kullanımı olmuştur. Alanyazındaki bazı çalışmalarda da (Karakaya, 2013; Karataş, 2014; Pamuk vd., 2013; Adıgüzel ve Yüksel, 2012) bunlara benzer entegrasyon sorunlarınları ile karşılaşıldığı sonuçlarına ulaşılmıştır.

TPAB yeterlilikleri ile teknoloji kullanma yeterliliği ilişkili olduğu için, TB boyutunda diğer boyutlara göre daha düşük düzeyde puan alınmasının nedenleri araştırılıp bu doğrultuda düzenlemeler yapılabilir, eğitimler verilebilir ve hizmet içi eğitimlerde düzenlemeye gidilebilir. Bunun yanı sıra, öğretmenlerin okullarında teknoloji entegrasyonu konusunda karşılaştıkları sorunlara çözümler bulunabilir. Teknoloji bilgisi ile ilişkili boyutlarda erkekler lehine anlamlı sonuçlar çıktığından verilecek hizmet içi eğitimlerde kadınlara pozitif ayrımcılık yapılarak bu noktada daha yeterli olmalarına katkı sağlanabilir. Etkileşimli tahta ve diğer öğretim teknolojilerini kullanma sıklıkları ile TPAB düzeylerinin pozitif ilişki içinde olduğu görüldüğünden, öğretmenlerin ihtiyaç duydukları teknolojilere erişim olanakları arttırılabilir.

Bu çalışmanın diğer çalışmalar ile çelişen sonuçları için aynı değişkenler kullanılarak farklı çalışmalar yürütülebilir. Farklı nicelik ve niteliklerdeki örneklemler ile yapılacak çalışmalarla benzerlik ve farklılaşma sebeplerine bakılabilir. Bu çalışma verileri karma yöntemle toplanmıştır. İleride yürütülecek çalışmalarda TPAB çerçevesini geliştirmeye yönelik deneysel çalışmalara yer verilebilir veya öğretmenlerin gerçek performanslarını tespit edebilmek için gözlem yöntemi kullanılabilir ve sınıf içi uygulamaları incelenebilir.

\section{KAYNAKÇA}

Abbitt, J. T. (2011). An investigation of the relationship between self-efficacy beliefs about technology integration and technological pedagogical content knowledge (TPACK) among preservice teachers. Journal of Digital Learning In Teacher Education, 27(4), 134-143.

Akçayır, M. (2011). Etkileşimli tahta kullanarak işlenen matematik dersinde sınıf öğretmenliği birinci sınıf ögrencilerinin başarı, tutum ve motivasyonları üzerine bir araştırma (Yayınlanmamış yüksek lisans tezi). Gazi Üniversitesi, Eğitim Bilimleri Enstitüsü, Ankara.

Akdemir, E. (2009). Etkileşimli tahta uygulamalarının öğrencilerin coğrafya ders başarılarına etkisinin incelenmesi (Yayınlanmamış yüksek lisans tezi). Zonguldak Karaelmas Üniversitesi, Sosyal Bilimler Enstitüsü, Zonguldak .

Akgün F. (2013). Öğretmen adaylarının web pedagojik içerik bilgileri ve öğretmen öz-yeterlilik algıları ile ilişkisi. Trakya Üniversitesi Eğitim Fakültesi Dergisi, 3(1), 48-58.

Akkaya, E. (2009). Matematik öğretmen adaylarının türev kavramına ilişskin teknolojik pedagojik alan bilgilerinin ögrrenci zorlukları bağlamında incelenmesi (Yayınlanmamış yüksek lisans tezi). Marmara Üniversitesi, Eitim Bilimleri Enstitüsü, İstanbul.

Akyüz, H. İ., Pektaş, M., Kurnaz, M. A., ve Memiş, E. K. (2014). Akıllı tahta kullanımlı mikro öğretim uygulamalarının fen bilgisi öğretmen adaylarının TBAP'larına ve akıllı tahta kullanıma yönelik algılarına etkisi. Cumhuriyet International Journal of Education, 3(1), 1-14.

Altınçelik, B. (2009). İlköğretim düzeyinde öğrenmede kalıcılı̆̆ ve motivasyonu sağlaması yönünden akıllı tahtaya iliş̧in öğretmen görüşleri (Yayınlanmamış yüksek lisans tezi). Sakarya Üniversitesi, Sosyal Bilimler Enstitüsü, Sakarya.

Amiri, R., \& Sharifi, M. (2014). The influence of using interactive whiteboard on writings of efl students regarding adverbs. Procedia-Social and Behavioral Sciences, 98, 242-250.

Angeli, C., \& Valanides, N. (2008, March). TPCK in pre-service teacher education: Preparing primary education students to teach with technology. InAERA annual conference, New York. 
Archambault, L., \& Crippen, K. (2009). Examining TPACK among K-12 online distance educators in the United States. Contemporary Issues In Technology and Teacher Education, 9(1), 71-88.

Ateș, M. (2010). Ortaöğretim coğrafya derslerinde akıllı tahta kullanımı. Marmara Coğrafya Dergisi, 22, 409427.

Avcl, T. (2014). Fen bilimleri ögretmenlerinin teknolojik pedagojik alan bilgisi ve öz güven düzeylerinin belirlenmesi (Yayınlanmamış yüksel lisans tezi). Celal Bayar Üniversitesi, Fen Bilimleri Enstitüsü, Manisa.

Çelik, D. (2007). Öğretmen adaylarının cebirsel düşünme becerilerinin analitik incelenmesi (Doktora tezi). Karadeniz Teknik Üniversitesi, Fen Bilimleri Enstitüsü, Trabzon.

Çelen, F. K. Çelik, A., Seferoğlu, S. S. (2011). Türk eğitim sistemi ve PISA sonuçları, XIII. Akademik Bilişsim Konferansı, 2-4 Şubat 2011, İnönü Üniversitesi, Malatya.

Bakadam, E., \& Asiri, M. J. S. (2012). Teachers' perceptions regarding the benefits of using the interactive whiteboard (IWB): The case of a Saudi intermediate school. Procedia-Social and Behavioral Sciences, 64, 179-185.

Büyüköztürk, Ş. (2007). Sosyal bilimler için veri analizi el kitabı (8. baskı). Ankara: Pegem Yayıncılık.

Büyüköztürk Ş., Kılıç-Çakmak E., Akgün Ö.E., Karadeniz Ş. ve Demirel F. (2013). Bilimsel araştırma yöntemleri (15.Baskı). Ankara: Pegem Yayıncllı.

Bulut İ. ve Koçoğlu E. (2012). Sosyal bilgiler öğretmenlerinin akıllı tahta kullanımına ilişkin görüşleri (Diyarbakır ili örneği). Dicle Üniversitesi Ziya Gökalp Eğitim Fakültesi Dergisi, 19, 242-258.

Canbazoğlu Bilici, S. (2012). Fen bilgisi öğretmen adaylarının teknolojik pedagojik alan bilgisi ve özyeterlikleri (Yayınlanmamış doktora tezi). Gazi Üniversitesi, Eğitim Bilimleri Enstitüsü, Ankara.

Canbolat, N. (2011). Matematik öğretmen adaylarının teknolojik pedagojik alan bilgileri ile düşünme stilleri arasındaki ilişskinin incelenmesi (Yayınlanmamış yüksek lisans tezi). Selçuk Üniversitesi, Eğitim Bilimleri Enstitüsü, Konya.

Chai, C. S., Koh, J. H. L., Tsai, C. C., \& Tan, L. L. W. (2011). Modeling primary school pre-service teachers' Technological Pedagogical Content Knowledge (TPACK) for meaningful learning with information and communication technology (ICT). Computers \& Education, 57(1), 1184-1193.

Creswell, J. W. (2013). Research design: Qualitative, quantitative, and mixed methods approaches. Sage Publications.

Elaziz, M.F. (2008) İngilizce derslerinde akıllı tahta kullanımına yönelik öğrenci ve öğretmen tutumları (Yayınlanmamış yüksek lisans tezi). Bilkent Üniversitesi, Eğitim Bilimleri Enstitüsü, Ankara.

Ergene, B. (2011). Matematik öğretmen adaylarının türev kavramına ilișkin teknolojik pedagojik alan bilgilerinin çoklu temsiller bileșeninde incelenmesi (Yayınlanmamış yüksek lisans tezi). Marmara Üniversitesi, Eğitim Bilimleri Enstitüsü, İstanbul.

Fer, S. (2004). İngilizce öğretmenliği aday öğretmenlerinin meslek yaşamlarında kullanacakları ile üniversitedeki öğretim elemanlarının kullandığı öğretim materyalleri arasındaki ilişki. Eğitim Araștırmaları, 5(17), 147-163.

Games, P. A., Keselman, H. J., \& Clinch, J. J. (1979). Tests for homogeneity of variance in factorial designs. Psychological Bulletin, 86(5), 978.

Gömleksiz, M. N., \& Fidan, E. K. (2011). Pedagojik Formasyon Programı Öğrencilerinin Web Pedagojik İçerik Bilgisine İliş̧kin Öz-Yeterlik Algı Düzeyleri.Turkish Studies International Periodical for the Languages, Literature and History of Turkish or Turkic, 6(4), 593-620.

Graham, C. R., Burgoyne, N., Cantrell, P., Smith, L., St. Clair, L. \& Harris, R. (2009). TPACK development in science teaching: Measuring the TPACK confidence of inservice science teachers. Techtrends: Linking Research \& Practice To Improve Learning, 53(5), 70-79. 
Grossman, P. L. (1990). The making of a teacher: Teacher knowledge and teacher education. New York: Teachers College Press.

ISTE. (2008). National educational technology standards and performance indicators for teachers (Nets-T). [Çevrim-içi http://www.iste.org/standards/standards-for-teachers], Erişim tarihi: 24.12.2014.

Jang, S. J. (2010). Integrating the interactive whiteboard and peer coaching to develop the TPACK of secondary science teachers. Computers \& Education, 55(4), 1744-1751.

Jang, S. J. \& Tsai, M. F. (2012). Exploring the TPACK of Taiwanese elementary mathematics and science teachers with respect to use of interactive whiteboards. Computers \& Education, 59(2), 327-338.

Jang, S. J., \& Tsai, M. F. (2013). Exploring the TPACK of Taiwanese secondary school science teachers using a new contextualized TPACK model. Australasian Journal of Educational Technology, 29(4).

Karakaya, Ç. (2013). Ortaöğretim matematik öğretmenlerinin teknolojik pedagojik alan bilgilerinin ve teknolojiyi entegre etme öz yeterliliklerinin incelenmesi (Yayınlanmamıș yüksek lisans tezi). Gazi Üniversitesi, Eğitim Bilimleri Enstitüsü, Eğitim Bilimleri Enstitüsü, Ankara.

Karataş, A. (2014). Lise öğretmenlerinin FATiH projesi'ni uygulamaya yönelik teknolojik pedagojik alan bilgisi yeterliliklerinin incelenmesi: Adlyaman ili örneği (Yayınlanmamış yüksek lisans tezi). Sakarya Üniversitesi, Eğitim Bilimleri Enstitüsü, Sakarya.

Katwibun, H. (2014). Using an interactive whiteboard in vocabulary teaching. Procedia-Social And Behavioral Sciences, 116, 674-678.

Kaya, Z., Kaya, O. N., ve Emre, İ. (2013). Teknolojik pedagojik alan bilgisi (TPAB) ölçeği'nin Türkçeye uyarlanması. Kuram ve Uygulamada Eğitim Bilimleri, Educational Sciences: Theory \& Practice, 13(4). 23552377.

Kayaduman, H., Sırakaya, M., ve Seferoğlu, S. S. (2011). Eğitimde FATï projesinin öğretmenlerin yeterlik durumları açısından incelenmesi. XIII. Akademik Bilişim Konferansı, 2 - 4 Şubat 2011, İnönü Üniversitesi, Malatya.

Kılıç, A. (2011). Fen ve teknoloji öğretmen adaylarının elektrik akımı konusundaki teknolojik pedagojik alan bilgilerinin ve sınıf içi uygulamalarının araştırılması (Yayınlanmamış yüksek lisans tezi). Fırat Üniversitesi, Fen Bilimleri Enstitüsü, Elazığ.

Koçak, Ö. (2013). FATiH projesi kapsamındaki LCD panel etkileşimli tahta uygulamalarına yönelik öğretmen tutumları (Erzincan ili örneği) (Yayınlanmamış yüksek lisans tezi). Atatürk Üniversitesi, Eğitim Bilimleri Enstitüsü, Erzurum.

Koehler, M. J., \& Mishra, P. (2005). What happens when teachers design educational technology? The development of technological pedagogical content knowledge. Journal of Educational Computing Research, 32(2), 131-152.

Koehler, M.J., \& Mishra, P., \& Yahya, K. (2007). Tracing the development of teacher knowledge in a design seminar: Integrating content, pedagogy and technology. Computers \& Education, 49(3), 740-762.

Koh, J. H., \& Divaharan, H. (2011). Developing pre-service teachers' technology integration expertise through the TPACK-developing instructional model. Journal of Educational Computing Research, 44(1), 35-58.

Lye, L. T. (2013). Opportunities and challenges faced by private higher education institution using the TPACK model in Malaysia. Procedia-Social And Behavioral Sciences, 91, 294-305.

MEB. (2006). Öğretmenlik mesleği genel yeterlikleri. [Çevrim-içi: http://oyegm.meb.gov.tr/yet/], Erişim tarihi: 24.12.2014.

MEB. (2012). Milli eğitim bakanlığı FATiH projesi. [Çevrim-içi: http://fatihprojesi.meb.gov.tr], Erişim tarihi: 09.06.2015.

Mishra, P. \& Koehler, M. J. (2006). Technological pedagogical content knowledge: A framework for integrating technology in teacher knowledge. Teachers College Record, 108(6), 1017-1054. 
Niess, M. L. (2005). Preparing teachers to teach science and mathematics with technology: Developing a technology pedagogical content knowledge. Teaching and Teacher Education, 21(5), 509-523.

Özbek A. (2014). Öğretmenlerin yenilikçilik düzeylerinin TPAB yeterlikleri üzerindeki etkisinin incelenmesi (Yayınlanmamış yüksek lisans tezi). Necmettin Erbakan Üniversitesi, Eğitim Bilimleri Enstitüsü, Konya.

Öztan, A.C. (2012). Fen ve teknoloji ögrretiminde akıllı tahta kullanımının ilköğretim 7. sınıf öğrencilerinin akademik başarılarına etkisi (Yayınlanmamış yüksek lisans tezi). Necmettin Erbakan Üniversitesi, Eğitim Bilimleri Enstitüsü, Konya.

Perkmen, S. ve Tezci, E. (2011). Eğitimde teknoloji entegrasyonu (s.1-7). Ankara: Pegem Akademi Yayıncılık.

Schmidt, D. A., Baran, E., Thompson, A. D., Mishra, P., Koehler, M. J., \& Shin, T. S. (2009). Technological pedagogical content knowledge (TPACK): The development and validation of an assessment instrument for preservice teachers. Journal of Research On Technology In Education, 42(2), 123-149.

Seferoğlu, S. S. (2004). Öğretmen yeterlilikleri ve mesleki gelişim. Eğitim Dergisi, 58, 40-41.

Shulman, L. S. (1986). Those who understand: Knowledge growth in teaching. Educational Researcher, 15(2), 414.

Shin, T., Koehler, M., Mishra, P., Schmidt, D., Baran, E., \& Thompson, A. (2009, March). Changing technological pedagogical content knowledge (TPACK) through course experiences. In Society for Information Technology \& Teacher Education International Conference (Vol. 2009, No. 1, pp. 4152-4159).

Smith, H. J., Higgins, S., Wall, K., \& Miller, J. (2005). Interactive whiteboards: Boon or bandwagon? A critical review of the literature. Journal of Computer Assisted Learning, 21(2), 91-101.

Tataroğlu, B. (2009). Matematik öğretiminde akıllı tahta kullanımının 10. sınıföğrencilerinin akademik başarıları, matematik dersine karşı tutumları ve özyeterlik düzeylerine etkileri (Yayınlanmamış yüksek lisans tezi). Dokuz Eylül Üniversitesi, Eğitim Bilimleri Enstitüsü, İzmir.

Tatli, C., \& Kilic, E. (2015). Interactive whiteboards: Do teachers really use them interactively? Interactive Learning Environments, (ahead-of-print), 1-17.

Timur, B. ve Taşar, M. F. (2011). Teknolojik pedagojik alan bilgisi öz güven ölçeğinin (TPABÖGÖ) Türkçe'ye uyarlanması. University of Gaziantep Journal of Social Sciences, 10(2), 839-856.

Türel, Y. K. (2012). Teachers' negative attitudes towards interactive whiteboard use: Needs and problems. Elementary Education Online, 11(2), 423-439.

Uzun, N. (2013). Dinamik geometri yazılımlarının bilgisayar destekli öğretim ve akıllı tahta ile zenginleştirilmiş öğrenme ortamlarında kullanımının öğrencilerin akademik başarısına, uzamsal görselleștirme becerisine ve uzamsal düşünme becerisine ilişkin tutumlarına etkisi (Yayınlanmamış yüksek lisans tezi). Gazi Üniversitesi, Eğitim Bilimleri Enstitüsü, Ankara.

Yurdakul I. K. (2011). Öğretmen adaylarının teknopedagojik eğitim yeterliliklerinin bilgi ve iletişim teknolojileri kullanımı açısından incelenmesi. Hacettepe Üniversitesi Eğitim Fakültesi Dergisi (H. U. Journal of Education), 40, 397-408.

Zengin, F.K., Kırılmazkaya, G. ve Keçeci, G. (2011). Akıllı tahta kullanımının ilköğretim öğrencilerinin fen ve teknoloji dersindeki bașarı ve tutuma etkisi. 5th International Computer \& Instructional Technologies Symposium, S. 27702-27707. 